\title{
Evaluation of the Phytoestrogenic Activity of Cyclopia genistoides (Honeybush) Methanol Extracts and Relevant Polyphenols
}

\author{
Nicolette J. D. Verhoog, ${ }^{\dagger}$ Elizabeth Joubert, ${ }^{\ddagger}, \S$ AND Ann Louw $*, \dagger$ \\ Department of Biochemistry, and Department of Food Science, Stellenbosch University, Stellenbosch \\ 7600, South Africa, and Post-Harvest \& Wine Technology Division, ARC Infruitec-Nietvoorbij, \\ Stellenbosch 7600, South Africa
}

\begin{abstract}
Unfermented C. genistoides methanol extracts of different harvestings and selected polyphenols were evaluated for phytoestrogenic activity by comparing binding to both ER subtypes, transactivation of an ERE-containing promoter reporter, proliferation of MCF-7-BUS and MDA-MB-231 breast cancer cells, and binding to SHBG. The extracts from one harvesting of $C$. genistoides (P104) bound to both ER subtypes. All extracts transactivated ERE-containing promoter reporters via ER $\beta$ but not via $E R \alpha$. All extracts, except P122, caused proliferation of the estrogen-sensitive MCF-7-BUS cells. Proliferation of MCF-7-BUS cells was ER-dependent as ICI 182,780 reversed proliferation. Physiologically more relevant, extracts antagonized $\mathrm{E}_{2}$-induced MCF-7-BUS cell proliferation. Furthermore, all extracts, except P122, induced proliferation of the estrogen-insensitive MDA-MB-231 cells, suggesting that the extracts are able to induce ER-dependent and ER-independent cell proliferation. Binding to SHBG by extracts was also demonstrated. These results clearly show that $C$. genistoides methanol extracts display phytoestrogenic activity and act predominantly via ER $\beta$. HPLC and LCMS analysis, however, suggests that the observed phytoestrogenic activity cannot be ascribed to polyphenols known to be present in other Cyclopia species.
\end{abstract}

KEYWORDS: Phytoestrogens; ER $\alpha$; ER $\beta$; MCF-7-BUS cell proliferation; MDA-MB-231 cell proliferation; SHBG; honeybush; Cyclopia genistoides

\section{INTRODUCTION}

Cyclopia genistoides, a fynbos shrub, together with $C$. subternata, $C$. intermedia, and to a lesser extent $C$. sessiliflora, are commercially available as the fragrant caffeine-free honeybush tea. Honeybush tea has already been identified as having both antioxidant and antimutagenic activity, which adds value to this herbal infusion (1). The presence of the known phytoestrogens, formononetin, eriodictyol, and naringenin, in $C$. intermedia (2) and luteolin in both $C$. intermedia and $C$. subternata $(2,3)$ plus anecdotal evidence that honeybush tea helps alleviate menopausal symptoms led to the investigation of putative phytoestrogenic activity in Cyclopia spp.

Phytoestrogens are plant polyphenols able to mediate weak estrogenic or anti-estrogenic activity (4). Most research investigating phytoestrogens has concentrated on soybean and the isoflavone, genistein, a well-documented phytoestrogen abundantly present in soy (5). Epidemiological studies suggest that an Asian diet rich in soy is protective against hormone-induced cancers such as breast and prostate cancer (6-9). In addition,

* Author to whom correspondence should be addressed [telephone +27 21-8085873; fax +27 21 8085863; e-mail al@sun.ac.za].

Department of Biochemistry, Stellenbosch University.

Department of Food Science, Stellenbosch University.

$\S$ ARC Infruitec-Nietvoorbij. phytoestrogens are thought to be useful for the treatment of menopausal symptoms and to protect postmenopausal women against cardiovascular disease and osteoporosis, without the risks associated with traditional hormone replacement therapy (HRT) $(10-14)$. However, some studies have failed to show significant alleviation of menopausal symptoms, such as hot flushes, while other studies, although showing some efficacy, suggest that phytoestrogen treatment is not as effective as traditional HRT $(15-17)$. Recently, the safety of long-term use of traditional HRT has been questioned by several studies $(18-20)$. This and the general increase in popularity of natural medicine have lent impetus to the search for and investigation into alternative treatments (21).

A previous study by our group (22), which screened extracts from the four commercially available Cyclopia species for estrogenic activity through binding to the ER subtypes, identified methanol extracts from $C$. genistoides as consistently having the highest binding affinity for both ER subtypes.

The biological responses to estrogen are mediated mainly via the estrogen receptor (ER) subtypes, $\operatorname{ER} \alpha$ and $\operatorname{ER} \beta$ (23). The ERs are ligand-activated transcription factors (24) that dissociate from heat shock proteins on activation by ligand. Activation also involves a conformational change, which allows dimerization and binding to estrogen response elements (EREs) 
Table 1. Details of C. genistoides Plant Material Harvested, Dried Methanol Extracts (DMEs) Prepared from the Harvestings, and Extract Yield and Total Polyphenol (TPP) Content of DMEs

\begin{tabular}{|c|c|c|c|c|c|c|}
\hline species & harvesting $^{a}$ & area harvested & date of harvesting & extract & extract yield $(\%)^{b}$ & TPP content $(\%)^{c}$ \\
\hline \multirow{6}{*}{$\begin{array}{l}\text { C. genistoides } \\
\text { (West Coast type) }\end{array}$} & \multirow[t]{2}{*}{ P104 } & \multirow{2}{*}{$\begin{array}{l}\text { Koksrivier, } \\
\text { Pearly Beach }\end{array}$} & \multirow[t]{2}{*}{15 March 2001} & $\mathrm{O}^{d} \mathrm{P} 104$ & 13.35 & 22.31 \\
\hline & & & & Ne P104 & 16.93 & 23.53 \\
\hline & \multirow[t]{2}{*}{ P105 } & \multirow{2}{*}{$\begin{array}{l}\text { Koksrivier, } \\
\text { Pearly Beach }\end{array}$} & \multirow[t]{2}{*}{28 March 2001} & OP105 & 13.41 & 21.99 \\
\hline & & & & N P105 & 16.28 & 23.89 \\
\hline & \multirow[t]{2}{*}{ P122 } & \multirow{2}{*}{$\begin{array}{l}\text { Koksrivier, } \\
\quad \text { Pearly Beach }\end{array}$} & \multirow[t]{2}{*}{31 March 2003} & OP122 & 18.94 & 25.02 \\
\hline & & & & N P122 & 16.43 & 24.87 \\
\hline
\end{tabular}

${ }^{a}$ The abbreviations used for the harvestings are also used for the dry methanol extracts (DMEs) prepared from these harvestings. Although all harvestings were done on the same plantation, they were done at different times. Two extracts were prepared of each harvesting. ${ }^{b}$ Yield $=\mathrm{g}$ of freeze-dried extract per $100 \mathrm{~g}$ of dried pulverized plant material. ${ }^{c}$ TPP content $=\mathrm{g}$ of gallic acid equiv per $100 \mathrm{~g}$ of of freeze-dried extract. ${ }^{d}$ First methanol extract of the same harvesting. ${ }^{e}$ Second methanol extract of the same harvesting (prepared at a later stage).

situated in the promoter region of estrogen responsive genes thereby activating or inhibiting transcription (23). Phytoestrogens are able to compete with $17-\beta$-estradiol $\left(\mathrm{E}_{2}\right)$ for binding to the ER subtypes and are able to act as either agonist or antagonist when bound to the ERs (25). Phytoestrogens generally bind to the ER subtypes with a much lower affinity than $\mathrm{E}_{2}$ and display, unlike $E_{2}$, a higher affinity for $\operatorname{ER} \beta$ than for $\operatorname{ER} \alpha(25,26)$. In addition, phytoestrogens have been shown to induce transactivation via both ER subtypes (27), with an increased transcriptional response through $\operatorname{ER} \beta$. They are, however, less potent than $\mathrm{E}_{2}$ via both ER subtypes $(27,28)$.

Estrogens are responsible for the proliferation and differentiation of a number of tissues (29), and this property is often used to evaluate estrogenicity (30). Hyper-proliferation can cause or enhance the spread of cancer (31). The $\operatorname{ER} \beta$ subtype is believed to be a negative modulator of $\mathrm{ER} \alpha$-mediated activity as it has been demonstrated to inhibit transactivation and cell proliferation when coexpressed with $\operatorname{ER} \alpha(32-34) . \mathrm{ER} \beta$ is thus believed to be the natural cellular protective mechanism against excessive cell proliferation mediated by $\mathrm{ER} \alpha$, and numerous studies concentrate on compounds, such as phytoestrogens, which are able to distinguish between the two ER subtypes with preferential binding to and/or transactivation via $\operatorname{ER} \beta$ (33).

Estrogens circulating in the blood are transported primarily bound to serum albumin or sex hormone-binding globulin (SHBG) (35). Only unbound estrogens are able to diffuse across the cell membrane and mediate an estrogenic response (36). It has been suggested that phytoestrogens may alter the concentration of biologically active endogenous estrogens, by either binding to SHBG and displacing bound estrogens or by stimulating SHBG synthesis (37). It is thus clear that phytoestrogens not only have a direct effect on estrogen signaling through binding to the ER subtypes, but also an indirect effect through altering the concentrations of biologically active estrogens.

In the present study, methanol extracts from $C$. genistoides (Table 1) as well as known polyphenols present in Cyclopia spp., which either were shown to bind to both ER subtypes (luteolin, formononetin, and naringenin) or were present at very high concentrations such as mangiferin, were further investigated (Figure 1). Although useful as an initial screening technique, binding to the ER subtypes alone does not distinguish agonist from antagonist activity, and thus the present study extends the initial investigation (22) by including a number of other in vitro assays such as the transactivation of an ERE-containing promoter reporter construct, cell proliferation of two breast cancer cells, and binding to SHBG. In addition, HPLC and LCMS analysis was done on the specific methanol extracts<smiles>O=c1cc(-c2ccc(O)c(O)c2)oc2cc(O)cc(O)c12</smiles><smiles>COc1ccc(-c2coc3cc(O)ccc3c2=O)cc1</smiles>

formononetin<smiles>O=C1CC(c2ccc(O)cc2)Oc2cc(O)cc(O)c21</smiles><smiles>[R]c1c(O)cc2oc3cc(O)c(O)cc3c(=O)c2c1O</smiles>

naringenin<smiles>CC12CCC3c4ccc(O)cc4CCC3C1CCC2O</smiles>

mangiferin $\mathrm{R}_{1}=2-\beta-D$-glucopyranosyl<smiles>O=c1c(-c2ccc(O)cc2)coc2cc(O)cc(O)c12</smiles>

genistein

17-3-estradiol

Figure 1. Chemical structures of the plant polyphenols investigated together with that of $\mathrm{E}_{2}$.

investigated to quantify and confirm the identity of the polyphenols known to be present in other Cyclopia species.

\section{MATERIALS AND METHODS}

Test Compounds Used. 17- $\beta$-Estradiol, genistein, mangiferin, and naringenin were purchased from Sigma-Aldrich (Cape Town, South Africa), and luteolin and formononetin were from Extrasynthese (Genay, France)

Dried Methanol Extract (DME) Preparation. Two methanol extracts of unfermented $C$. genistoides were prepared from each of three independent harvestings. The extraction was repeated to compare different methanol extractions of the same plant material (Table 1). Cyclopia genistoides plants were chosen randomly in a plantation, and several bushes were harvested on each occasion. The harvested plant material (Table 1), comprising intact stems and leaves, was dried whole at $40{ }^{\circ} \mathrm{C}$ to less than $10 \%$ moisture content, whereafter it was milled (1 $\mathrm{mm}$ sieve) and stored at room temperature in a sealed container. Dried, pulverized, unfermented plant material $(25 \mathrm{~g})$ was extracted three times with $50 \mathrm{~mL}$ of dichloromethane at room temperature for $20 \mathrm{~h}$ each, filtered through Whatman No. 4 filter paper with a Buchner funnel, and the filtrate was discarded. Thereafter, methanol extraction $(50 \mathrm{~mL})$ of the air-dried plant material was performed twice at room temperature for $20 \mathrm{~h}$ each. The methanol extracts were pooled with a 
small volume of water added and evaporated under vacuum before freeze-drying. Freeze-dried DMEs were ground in a darkened room to a fine homogeneous powder, which was stored in glass vials, covered with aluminum foil, and placed in vacuum-sealed desiccators in the dark at room temperature.

Cell Culture. COS-1 cells (ATCC) and estrogen-insensitive MDAMB-231 cells (38) (a kind gift from G. Haegemann, University of Gent, Belgium) were maintained in DMEM supplemented with $10 \%(\mathrm{v} / \mathrm{v})$ fetal calf serum (FCS) and a penicillin $(100 \mathrm{IU} / \mathrm{mL})$ and streptomycin (100 $\mu \mathrm{L} / \mathrm{mL})$ mixture (penicillin-streptomycin). The ER $\alpha$ and $\operatorname{ER} \beta$ positive MCF-7-BUS cells (38) (a kind gift from A. Soto, Tufts University, U.S.) were maintained in DMEM supplemented with 5\% $(\mathrm{v} / \mathrm{v})$ heat inactivated FCS, but without antibiotics. All cells were maintained in a humidified cell incubator set at $97 \%$ relative humidity and $5 \% \mathrm{CO}_{2}$ at $37{ }^{\circ} \mathrm{C}$.

Transient Transfections and Whole Cell Binding Assays in COS-1 Cells. COS- 1 cells were plated at a density of $2 \times 10^{6}$ cells per $10 \mathrm{~cm}$ tissue culture dish. Twenty-four hours after plating, COS-1 cells were transiently transfected with expression vectors for the ER subtypes, pcDNA3-hER $\alpha$ (a kind gift from D. Harnish, Womens's Health Research Institute, Wyeth-Ayerst Research, U.S.) or pSG5-hER $\beta$ (a kind gift from F. Gannon, European Molecular Biology Laboratory, Heidelberg, Germany) and a filler vector, pGL2-basic (Promega Corp., Madison, WI). Two different transfections methods were used to transfect the ER subtypes. The Fugene6 transfection reagent was used for the hER $\alpha$ transfections, and the DEAE-Dextran transfection method was used for $\mathrm{hER} \beta$ transfections. The total DNA transfected for both transfection protocols was $6 \mu \mathrm{g} / 10 \mathrm{~cm}$ dish that consisted of $0.72 \mu \mathrm{g}$ of receptor and $5.28 \mu \mathrm{g}$ of empty vector. The Fugene6 transfection protocol, used for hER $\alpha$, was per the manufacturer's instructions with $12 \mu \mathrm{L}$ of Fugene6 reagent allowed to react with $6 \mu \mathrm{g}$ of DNA. The DEAE-Dextran transfection medium, used for $\mathrm{hER} \beta$, consisted of 5 $\mathrm{mL}$ of DMEM, pre-heated to $37^{\circ} \mathrm{C}, 0.1 \mathrm{mM}$ chloroquine (stock solution $100 \mathrm{mM}), 6 \mu \mathrm{g}$ of DNA, and finally $0.1 \mathrm{mg} / \mathrm{mL}$ DEAE-Dextran solution (stock solution $10 \mathrm{mg} / \mathrm{mL}$ ). Cells were incubated with the DEAE-Dextran transfection medium for $1 \mathrm{~h}$ at $37^{\circ} \mathrm{C}$ after which they were shocked with $10 \mathrm{~mL}$ of pre-heated $10 \%$ DMSO-PBS for about 2 min. Finally, transiently transfected cells were incubated at $37{ }^{\circ} \mathrm{C}$ overnight in DMEM supplemented with $10 \%$ FCS and $1 \%$ penicillinstreptomycin mixture. The following day the transfected COS-1 cells were pooled and seeded into 24 -well tissue culture plates at a density of $5 \times 10^{4}$ cells/well and incubated for $24 \mathrm{~h}$. The next day the cells were washed three times with $500 \mu \mathrm{L}$ of PBS/well (pre-heated at 37 $\left.{ }^{\circ} \mathrm{C}\right)$. This was followed by a 2-h incubation of the transfected cells with $10^{-9} \mathrm{M}$ radiolabeled estradiol $\left(2,4,6,7-{ }^{3} \mathrm{H}-17-\beta\right.$-estradiol from Amersham, Cape Town, South Africa, with specific activity $87.0 \mathrm{Ci} /$ mmol and counting efficiency of $46 \%$ ) and various concentrations, ranging from $2.7 \times 10^{-13}$ to $7.94 \times 10^{-3} \mathrm{mg} / \mathrm{mL}$, of unlabeled competitors, that is, extracts and polyphenols (dissolved in DMSO) in DMEM without phenol red and FCS. All assays included a total binding point, which was in the presence of $0.1 \% \mathrm{DMSO}$, and $\mathrm{E}_{2}$ and genistein as positive controls. After the $2 \mathrm{~h}$ incubation period, the cells were immediately placed on ice, and further work was done at $4{ }^{\circ} \mathrm{C}$. Cells were washed three times with $1 \mathrm{~mL}$ of $0.2 \%$ bovine serum albuminPBS with an interval of $15 \mathrm{~min}$ between washes to remove free ligand. Cells were then lysed with $50 \mu \mathrm{L}$ of lysis buffer $(0.2 \%$ (v/v) Triton, $10 \%(\mathrm{v} / \mathrm{v})$ glycerol, $2.8 \%(\mathrm{v} / \mathrm{v})$ Tris-phosphate-EDTA, and $1.44 \mathrm{mM}$ EDTA) per well. For effective lysis, plates were placed on a shaker for approximately $15 \mathrm{~min}$ and thereafter allowed to freeze at $-20{ }^{\circ} \mathrm{C}$. On thawing of samples, $5 \mu \mathrm{L}$ of lysate was used for protein determination using the Bradford method (39). Another $50 \mu \mathrm{L}$ of lysis buffer was added to the remaining lysate in the wells, and this was transferred to scintillation vials to which $3 \mathrm{~mL}$ of scintillation fluid (Quickszint FLOW 2; Zinsser Analytic, Cape Town, South Africa) was added. Radioactivity of the assay samples was determined using a Beckman LS 3801 Beta-scintillation counter. The protein concentrations were used to normalize radioactivity readings, and results are expressed as percentage of normalized control with total binding (in presence of $0.1 \%$ DMSO) taken as $100 \%$. All binding experiments also included a control for ligand depletion. The ligand depletion for all whole cell ER binding experiments was less than $10 \%$.
Transient Transfections and ERE-Containing Promoter Reporter Assays in COS-1 Cells. The cells were transfected using the Fugene6 reagent as per the manufacturer's instructions. For hER $\alpha$ transfection, COS- 1 cells $\left(5 \times 10^{4}\right.$ cells/well $)$ were directly transfected in 24-well dishes $24 \mathrm{~h}$ after plating. Briefly, $300 \mathrm{ng}$ of total DNA/well, consisting of $5 \mathrm{ng}$ of hER $\alpha$ (pSG5-hER $\alpha$, a kind gift from F. Gannon, European Molecular Biology Laboratory, Heidelberg, Germany) expression plasmid, $200 \mathrm{ng}$ of ERE-containing promoter reporter construct (ERE.vit2.luc, a kind gift from K. Korach, National Institute of Environmental Health Science, U.S.), 5 ng of pCMV- $\beta$-galactosidase (Stratagene, La Jolla, CA) for normalization of transfection efficiency, and $90 \mathrm{ng}$ of empty vector (pGL2-Basic) were used with $0.6 \mu \mathrm{L}$ of Fugene6 for $\mathrm{hER} \alpha$ transfections. Cells were induced $24 \mathrm{~h}$ after transfection. For hER $\beta$ transfections, COS- 1 cells were plated at a density of $2 \times 10^{6}$ cells $/ 10 \mathrm{~cm}$ dish and transfected $24 \mathrm{~h}$ after plating. A total of $9.6 \mu \mathrm{g}$ of DNA consisting of $0.8 \mu \mathrm{g}$ of hER $\beta$ (pSG5-hER $\beta$, also a gift from F.Gannon) expression plasmid, $8 \mu \mathrm{g}$ of ERE.vit2.luc, and $0.8 \mu \mathrm{g}$ of pCMV- $\beta$-galactosidase were transiently transfected using $19.2 \mu \mathrm{L}$ of Fugene6 reagent/dish. The following day cells were pooled and seeded at a density of $5 \times 10^{4}$ cells per well into 24-well tissue culture plates and incubated for $24 \mathrm{~h}$ before induction. Transfected cells were induced for $24 \mathrm{~h}$ with various concentrations of polyphenol compounds or DMEs (dissolved in DMSO) ranging from $2.7 \times 10^{-13}$ to $7.94 \times 10^{-3} \mathrm{mg} / \mathrm{mL}$. All assays included a negative control, which consisted of $0.1 \%(\mathrm{v} / \mathrm{v})$ DMSO only, and $\mathrm{E}_{2}$ and genistein as positive controls. After induction the medium was aspirated, $50 \mu \mathrm{L}$ of lysis buffer (Tropix Inc. (Applied Biosystems, Bedford, MA)) was added, and cells were frozen at $-20{ }^{\circ} \mathrm{C}$ overnight. Luciferase assay reagent (Promega Corp., Madison, WI) was used to quantify luciferase activity in accordance with the manufacturer's instructions. Briefly, $10 \mu \mathrm{L}$ of cell lysate was allowed to react with $50 \mu \mathrm{L}$ of luciferase assay reagent. The relative light units (RLU's) were measured using the Veritas luminometer. A further $5 \mu \mathrm{L}$ of cell lysate for each sample was used to measure $\beta$-galactosidase activity with the $\beta$-galactosidase chemiluminescent Galacto-Star reporter gene assay system for mammalian cells (Tropix Inc. (Applied Biosystems, Bedford, MA)). Luciferase RLU's were normalized with $\beta$-galactosidase readings, and results were expressed as normalized fold induction with negative controls $(0.1 \%$ DMSO) taken as 1.

MTT Cell Proliferation Assay. MCF-7 BUS and MDA-MB-231 cells were plated at a density of 2500 cells/well in 96-well plates and incubated for $24 \mathrm{~h}$. The cells were then washed with $200 \mu \mathrm{L}$ of PBS, pre-warmed to $37{ }^{\circ} \mathrm{C}$, followed by steroid starving for $72 \mathrm{~h}$ through addition of DMEM pre-warmed to $37{ }^{\circ} \mathrm{C}$ without phenol red, but supplemented with $5 \%$ charcoal stripped FCS and a $1 \%$ penicillinstreptomycin mixture. On day five the medium was aspirated and cells were induced with increasing concentrations, ranging from $2.7 \times 10^{-13}$ to $7.94 \times 10^{-3} \mathrm{mg} / \mathrm{mL}$, of test compounds or DMEs (in DMSO) prepared in DMEM without phenol red, but supplemented with $5 \%$ charcoal stripped FCS and a $1 \%$ penicillin-streptomycin mixture. Cells were then incubated for $48 \mathrm{~h}$ whereafter the colorimetric MTT (3-(4,5dimethylthiazolyl-2)-2,5-diphenyltetrazolium bromide) assay was preformed. The MTT assay entails that $5 \mathrm{~h}$ before the end of the incubation period the assay medium is changed to unsupplemented DMEM without phenol red whereafter $20 \mu \mathrm{L}$ of MTT solution $(5 \mathrm{mg} / \mathrm{mL})$ is added to each well. Cells were incubated for $5 \mathrm{~h}$ at $37^{\circ} \mathrm{C}$, the medium was then removed, and $200 \mu \mathrm{L}$ of solubilization solution (DMSO) was added to each well. The DMSO was pipetted up and down in the well to dissolve crystals until a uniform purple color had formed. The plate was then placed in a $37^{\circ} \mathrm{C}$ incubator for $5 \mathrm{~min}$, and the absorbance was read at $540 \mathrm{~nm}$ in a micotiter plate reader (Titertek Multiskan Plus, Titertek Instruments Inc., Huntsville, AL). All assays included a negative control, which consisted of $0.1 \%(\mathrm{v} / \mathrm{v})$ DMSO only, and $\mathrm{E}_{2}$ and genistein as positive controls. Results are expressed as fold induction with negative controls $(0.1 \%$ DMSO) taken as 1 .

Co-treatment by both $\mathrm{E}_{2}\left(10^{-9} \mathrm{M}\right)$ and the polyphenols $\left(10^{-5} \mathrm{M}\right.$ except for genistein, which was tested at $\left.10^{-7} \mathrm{M}\right)$ or DME $(9.8 \mu \mathrm{g} /$ $\mathrm{mL}$ ) was investigated. In addition, induction with test compounds and DME was investigated in the presence of $10^{-9} \mathrm{M}$ ER antagonist, ICI 182,780 . 
Table 2. Whole Cell Competitive Binding by $E_{2}$, Polyphenols, and DME to the hER Subtypes

\begin{tabular}{|c|c|c|c|c|c|c|c|c|}
\hline \multirow{2}{*}{$\begin{array}{c}\text { test } \\
\text { compounds }\end{array}$} & \multicolumn{2}{|c|}{$\mathrm{IC}_{50}(\mathrm{mg} / \mathrm{mL})^{a}$} & \multicolumn{2}{|c|}{$\operatorname{RBA}^{b}(\%)$} & \multirow{2}{*}{$\begin{array}{l}\beta / \alpha \text { of } \\
\mathrm{RBA}^{\mathrm{C}}\end{array}$} & \multicolumn{2}{|c|}{$K_{\mathrm{i}}^{d}(\mathrm{M})$} & \multirow[b]{2}{*}{$\beta / \alpha$ of $K_{i}^{c}$} \\
\hline & $\mathrm{hER} \alpha$ & $\mathrm{hER} \beta$ & $\mathrm{hER} \alpha$ & $\mathrm{hER} \beta$ & & $\mathrm{hER} \alpha$ & $\mathrm{hER} \beta$ & \\
\hline $\mathrm{E}_{2}$ & $3.7 \times 10^{-7}(3.63)^{\# \# e}$ & $7.3 \times 10^{-7}(4.74)$ & 100 & 100 & 1 & $0.37 \times 10^{-9} \mathrm{M}(5.44)$ & $1.17 \times 10^{-9} \mathrm{M}(5.01)$ & 0.3 \\
\hline genistein & $4.2 \times 10^{-5}(37.32)^{\star * f}$ & $9.0 \times 10^{-7}(1.23)$ & 0.73 & 81.11 & 111.10 & $43.1 \times 10^{-9} \mathrm{M}(8.99)^{*}$ & $1.01 \times 10^{-9} \mathrm{M}(4.98)$ & 42.7 \\
\hline luteolin & $1.5 \times 10^{-2}(4.88)^{\star \star \# \# ~}$ & $1.4 \times 10^{-4}(3.07)^{\star \star \# \# ~}$ & 0.003 & 0.52 & 173.35 & $12.20 \times 10^{-6} \mathrm{M}(25.61)^{* *}$ & $0.39 \times 10^{-6} \mathrm{M}(8.79)^{\star *}$ & 31.3 \\
\hline formononetin & $4.1 \times 10^{-5}(4.59)^{\star *}$ & $1.5 \times 10^{-4}(0.45)^{\star \star \# \#}$ & 0.93 & 0.48 & 0.52 & $34.51 \times 10^{-9} \mathrm{M}(9.51)^{*}$ & $0.14 \times 10^{-6} \mathrm{M}(7.52)^{\star *}$ & 0.25 \\
\hline naringenin & $3.9 \times 10^{-4}(8.33)^{\star *}$ & $1.5 \times 10^{-4}(2.88)^{\star \star \# \#}$ & 0.097 & 0.48 & 4.95 & $0.27 \times 10^{-6} \mathrm{M}(0.79)^{\star \star}$ & $0.11 \times 10^{-6} \mathrm{M}(10.46)^{* \star}$ & 2.5 \\
\hline mangiferin & & & NB & NB & NB & NB & NB & NB \\
\hline N P104 & $2.1 \times 10^{-4}(4.88)^{\star \star \# \#}$ & $1.3 \times 10^{-1}(26.28)^{\star \star \# \#}$ & 0.18 & 0.0006 & 0.003 & & & \\
\hline O P104 & $5.9 \times 10^{-4}(18.07)^{\star \star \# \#}$ & $2.3 \times 10^{-1}(19.24)^{\star \star \# \#}$ & 0.05 & 0.0003 & 0.006 & & & \\
\hline N P105 & NB & NB & NB & NB & NB & & & \\
\hline OP105 & NB & NB & NB & NB & NB & & & \\
\hline N P122 & NB & NB & NB & NB & NB & & & \\
\hline O P122 & NB & NB & NB & NB & NB & & & \\
\hline
\end{tabular}

${ }^{a}$ The $\mathrm{IC}_{50}$ and $\mathrm{CV}$ (coefficient of variation) values are calculated from the $\log \mathrm{IC}_{50}$ values from at least three independent experiments. ${ }^{b} \mathrm{RBA}$ or relative binding affinity is expressed relative to that of $\mathrm{E}_{2}(100 \%)$ and was calculated as follows: $100 \times I \mathrm{I}_{50}\left(\mathrm{E}_{2}\right) / \mathrm{IC}_{50}$ (test compound). ${ }^{c} \beta / \alpha$ ratio of RBA or $K_{\mathrm{i}}$ is such that the ratio is $>1$ for compounds having a higher affinity for $\mathrm{hER} \beta$ than $\mathrm{hER} \alpha,<1$ if compounds have a higher binding affinity for $\mathrm{hER} \alpha$ than $\mathrm{hER} \beta$, and equal to 1 for compounds having a similar affinity for both ER subtypes. The $\beta / \alpha$ ratio of RBA is calculated by RBA hER $\beta / \mathrm{RBA} h E R \alpha$, and the $\beta / \alpha$ ratio of $K_{\mathrm{i}}$ is calculated by $K_{\mathrm{i}} \mathrm{hER} \alpha / K_{\mathrm{i}} \mathrm{hER} \beta .{ }^{d} K_{\mathrm{i}}$ values were determined from the $K_{d}$ of $E_{2}$. The $K_{d}$ values of $E_{2}$ for $h E R \alpha$ and $h E R \beta$ were $0.37 \times 10^{-9} \pm 0.38 \mathrm{M}$ and $1.17 \times 10^{-9} \pm 0.18 \mathrm{M}$, respectively. ${ }^{e}$ Statistically different from genistein with "\#" representing $P<0.05$, "\#”" representing $P<0.01$, and "\#\#" representing $P<0.001$. ${ }^{f}$ Statistically different from $\mathrm{E}_{2}$ with "*” representing $P<0.05$, "**” representing $P<0.01$, and " "***" representing $P<0.001 .{ }^{g} \mathrm{NB}=$ non-binder polyphenols or extracts were unable to displace ${ }^{3} \mathrm{H}-\mathrm{E}_{2}$ from ER subtype.

Competitive SHBG Binding Assay. Displacement of $20 \times 10^{-9}$ $\mathrm{M}{ }^{3} \mathrm{H}-\mathrm{E}_{2}$ by test compounds and DME from SHBG was determined by the competitive SHBG binding assay as adapted from the method used by Hammond and Lähteenmäki (40). Pooled human pregnancy serum with a SHBG concentration of $408.6 \times 10^{-9} \mathrm{M}$ was diluted (1:100) with dextran-coated charcoal (DCC; $1.25 \mathrm{~g}$ of activated charcoal Norit CA1 and $0.125 \mathrm{~g}$ of $\mathrm{T} 70$ dextran were added to $500 \mathrm{~mL}$ of $0.02 \%$ gelatin-PBS mixture). Briefly, $20 \mu \mathrm{L}$ of pregnancy serum was added to $2 \mathrm{~mL}$ of DCC-slurry and mixed at room temperature for $30 \mathrm{~min}$. Following centrifugation at $5000 \mathrm{~g}$ at room temperature, the supernatant was collected, and $100 \mu \mathrm{L}$ of diluted serum was added to $100 \mu \mathrm{L}$ each of unlabeled $\mathrm{E}_{2}\left(10^{-5} \mathrm{M}\right)$, polyphenols $\left(10^{-5} \mathrm{M}\right)$, DME $(9.8 \mu \mathrm{g} / \mathrm{mL})$, and DMSO vehicle only (negative control) as competitors. This was followed by the addition of $100 \mu \mathrm{L}$ of PBS containing $60 \times 10^{-9} \mathrm{M}$ ${ }^{3} \mathrm{H}-\mathrm{E}_{2}$. The mixture was allowed to incubate for $1 \mathrm{~h}$ at room temperature followed by $15 \mathrm{~min}$ incubation in an ice-water bath kept at $4{ }^{\circ} \mathrm{C}$. The unbound ${ }^{3} \mathrm{H}-\mathrm{E}_{2}$ was then removed by incubating with $750 \mu \mathrm{L}$ of icecold DCC-slurry for $10 \mathrm{~min}$ followed by centrifugation at $3000 \mathrm{~g}$ for 3 $\min$ at $4{ }^{\circ} \mathrm{C}$. The supernatant was quickly decanted, and a constant volume $(750 \mu \mathrm{L})$ was added to scintillation vials containing $3 \mathrm{~mL}$ of scintillation fluid. Radioactivity was read on the Beckman LS 3801 scintillation counter. Results are expressed as the percentage $20 \times 10^{-9}$ $\mathrm{M}^{3} \mathrm{H}-\mathrm{E}_{2}$ displaced from SHBG. The total bound, that is, in the presence of vehicle (DMSO) only, represents $0 \%{ }^{3} \mathrm{H}-\mathrm{E}_{2}$ displaced from the SHBG.

HPLC and LC-MS Analysis. DAD-HPLC analysis of the extracts was carried out according to Verhoog et al. (22) on a Phenomenex Synergy MAX-RP 80A (C12 reversed-phase with TMS end-capping) column using an aqueous acetic acid-acetonitrile gradient with quantification at $280 \mathrm{~nm}$. For further confirmation of peak identity, the extracts were subjected to LC-MS analysis, using a Waters API Quattro Micro apparatus with a Waters 2690 quaternary HPLC pump and 996 photodiode array detector, and electrospray ionization operating in the negative mode. The operation conditions entailed: desolvation gas temperature $350^{\circ} \mathrm{C}$; nebulizing gas (nitrogen) flow rate, $500 \mathrm{~L} / \mathrm{h}$; source temperature, $120^{\circ} \mathrm{C}$; capillary voltage, $3500 \mathrm{~V}$; and cone voltage, $25 \mathrm{~V}$. Separation conditions was the same as for the HPLC analysis, except that the $2 \%$ acetic acid was replaced by $0.1 \%$ formic acid as the mobile phase. The same authentic standards of compounds tentatively identified by DAD-HPLC were analyzed for further confirmation of peak identity.

Data Manipulation and Statistical Analysis. The GraphPad Prism version 4.00 for Windows (GraphPad Software, San Diego, CA) was used for graphical representations and statistical analysis. One-way ANOVA and Dunnett's multiple comparisons' test as post-test were used for statistical analysis. $P$-values are represented as follows: statistically different from $\mathrm{E}_{2}$ by $*(P<0.05), * *(P<0.01)$, and $* * *$ $(P<0.001)$ and statistically different from genistein by ${ }^{\#}(P<0.05)$,

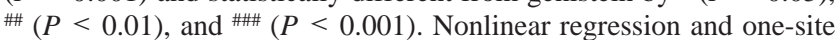
competition curve fitting were used to graph the data from the whole cell binding assays and to determine $\mathrm{IC}_{50}$ values. The relative binding affinity (RBA) is expressed relative to that of $\mathrm{E}_{2}(100 \%)$ and was calculated as follows: $100 \times \mathrm{IC}_{50}\left(\mathrm{E}_{2}\right) / \mathrm{IC}_{50}$ (test compound). The $K_{\mathrm{i}}$ values were determined from the $\mathrm{IC}_{50}$ values and $K_{\mathrm{d}}$ for $\mathrm{E}_{2}$ according to the equation by Cheng and Prusoff (41). Nonlinear regression and sigmoidal dose response curve fitting were used to graph the data from the ERE-containing promoter reporter and proliferation experiments and to determine fold induction and $\mathrm{EC}_{50}$. For all experiments, unless otherwise indicated, the error bars represent the SEM of three independent experiments done in triplicate.

\section{RESULTS}

Binding to ER Subtypes. All polyphenols were able to bind to both ER subtypes, except for the xanthone, mangiferin (Table 2). The order of potency for $h E R \alpha$ ( $\mathrm{IC}_{50}$ values) was $\mathrm{E}_{2} \gg$ formononetin $>$ genistein $>$ naringenin $\gg$ luteolin. Generally, all polyphenols, including genistein, bound to $\mathrm{ER} \alpha$ displayed significantly $(P<0.01)$ weaker binding than $\mathrm{E}_{2}$ with $\mathrm{RBA}$ values ranging from $0.93 \%$ for formononetin to $0.003 \%$ for luteolin. The order of potency for $\mathrm{hER} \beta$ was $\mathrm{E}_{2}>$ genistein $\gg$ luteolin $>$ formononetin $=$ naringenin. All polyphenol $\mathrm{IC}_{50}$ values for binding to $\mathrm{hER} \beta$ were significantly $(P<0.01)$ lower than those for $E_{2}$ and genistein with RBA values ranging from $0.48 \%$ for naringenin to $0.52 \%$ for luteolin. All of the polyphenols that bound, except formononetin, had a higher binding affinity for the $\mathrm{hER} \beta$, in contrast to $\mathrm{E}_{2}$ that had a slightly higher affinity for ER $\alpha$. Genistein, especially, had a very high binding affinity $\left(K_{\mathrm{i}}\right.$ value $\left.=1.01 \times 10^{-9} \mathrm{M}\right)$ for $\mathrm{hER} \beta$ and showed a strong preference for this subtype $\left(K_{\mathrm{i}} \beta / \alpha\right.$ ratio $\left.=42.7\right)$. Formononetin, similarly to $\mathrm{E}_{2}$, had a slight binding preference $\left(K_{\mathrm{i}} \beta / \alpha\right.$ ratio $\left.=0.25\right)$ for $\mathrm{hER} \alpha$.

The DME, even though from the same species, portrayed large variations in binding to the ER subtypes with only the two extracts from the P104 harvesting able to significantly $(P$ $<0.01)$ compete with ${ }^{3} \mathrm{H}-\mathrm{E}_{2}$ for binding to the ER subtypes (Table 2). O P104 displayed a lower potency than N P104. The binding potencies measured for hER $\alpha$ and hER $\beta$ of N P104 and O P104 were significantly different $(P<0.01)$ from those of $\mathrm{E}_{2}$ and genistein. Although N P104 in comparison to O P104 
Table 3. Potency $\left(E_{50}\right)$ and Efficacy (Maximal Fold Induction) Values As Determined from Transactivation of an ERE-Containing Promoter Reporter Gene Construct via $\mathrm{hER} \alpha$ or $\mathrm{hER} \beta$ for $\mathrm{E}_{2}$, Various Polyphenols, and the DME

\begin{tabular}{|c|c|c|c|c|}
\hline \multirow{2}{*}{$\begin{array}{l}\text { test compounds } \\
\text { or DME }\end{array}$} & \multicolumn{2}{|c|}{$\begin{array}{c}\text { potency } \\
\left(\mathrm{EC}_{50}\right)^{a} \mathrm{mg} / \mathrm{mL}\end{array}$} & \multicolumn{2}{|c|}{$\begin{array}{c}\text { efficacy } \\
\text { (maximal fold induction) }\end{array}$} \\
\hline & $\mathrm{hER} \alpha$ & $\mathrm{hER} \beta$ & $\mathrm{hER} \alpha$ & $\mathrm{hER} \beta$ \\
\hline$E_{2}$ & $3.70 \times 10^{-7}(0.49)^{b \# \# c}$ & $1.39 \times 10^{-7}(4.99)$ & $1.3(33.97)$ & $2.34(6.48)$ \\
\hline genistein & $9.03 \times 10^{-5}(8.15)^{* *}$ & $1.06 \times 10^{-6}(4.93)$ & $1.77(14.90)$ & $2.76(17.18)$ \\
\hline luteolin & $1.97 \times 10^{-3}(4.9)^{\star \star \star \# \# ~}$ & $3.53 \times 10^{-3}(38.69)^{\star \star \# \# d}$ & $2.41(26.57)$ & $3.69(48.22)$ \\
\hline formononetin & $1.01 \times 10^{-3}(4.36)^{* *}$ & $4.29 \times 10^{-5}(5.53)^{\star *}$ & $2.18(17.45)$ & $2.20(18.42)$ \\
\hline naringenin & N/A & $1.04 \times 10^{-4}(4.68)^{\star \star \#}$ & N/A & 2.99 (33.94) \\
\hline mangiferin & $\mathrm{N} / \mathrm{A}$ & $N / A^{e}$ & $\mathrm{~N} / \mathrm{A}$ & $\mathrm{N} / \mathrm{A}$ \\
\hline N P104 & $\mathrm{N} / \mathrm{A}$ & $1.51 \times 10^{-5}(22.60)^{*}$ & $\mathrm{~N} / \mathrm{A}$ & $2.44(36.78)$ \\
\hline OP104 & $\mathrm{N} / \mathrm{A}$ & $1.18 \times 10^{-5}(21.36)$ & $\mathrm{N} / \mathrm{A}$ & $2.39(21.11)$ \\
\hline N P105 & N/A & $9.20 \times 10^{-5}(12.31)$ & N/A & $1.63(3.25)$ \\
\hline O P105 & $N / A$ & $2.93 \times 10^{-5}(22.66)^{*}$ & $\mathrm{~N} / \mathrm{A}$ & $2.53(62.77)$ \\
\hline N P122 & $\mathrm{N} / \mathrm{A}$ & $6.90 \times 10^{-5}(0.21)$ & $\mathrm{N} / \mathrm{A}$ & $1.90(20.52)$ \\
\hline O P122 & $\mathrm{N} / \mathrm{A}$ & $2.48 \times 10^{-6}(0.59)$ & $\mathrm{N} / \mathrm{A}$ & $1.94(27.49)$ \\
\hline
\end{tabular}

\footnotetext{
${ }^{a} \mathrm{EC}_{50}$ values calculated from the $\log \mathrm{EC}_{50}$ values of three independent experiments given as the mean $(\mathrm{CV}) .{ }^{b} \mathrm{CV}$ (coefficient of variation) calculated from the log $\mathrm{EC}_{50}$ of at least three independent experiments performed in triplicate. " Statistically different from genistein with "\#” representing $P<0.05$, "\#\#" representing $P<0.01$, and "\#\#" representing $P<0.001 .{ }^{d}$ Statistically different from $E_{2}$ where "*" represents $P<0.05$ and "**" represents $P<0.01$. ${ }^{e} \mathrm{~N} / \mathrm{A}$ : test compound or DME did not induce the ERE-containing promoter reporter gene construct via the indicated hER subtype.
}

had higher potencies for both ER subtypes, they were not significantly $(P>0.05)$ different from each other (statistical data not shown). In contrast to most of the polyphenols investigated, formononetin and mangiferin excluded, P104 had a higher RBA and a stronger preference $(\operatorname{RBA} \beta / \alpha$ ratio $=0.003$ and 0.006 for N P104 and O P104, respectively) for the ER $\alpha$ subtype.

Transactivation of an ERE-Containing Promoter Reporter Construct via the hER Subtypes. $E_{2}$ transactivated $\mathrm{hER} \alpha$ and $\mathrm{hER} \beta$ with similar potencies, while the polyphenols generally, with the exception of luteolin, transactivated more potently via $\mathrm{hER} \beta$ (Table 3). The order of potency via $\mathrm{hER} \alpha$ was $\mathrm{E}_{2} \gg$ genistein $\gg$ formononetin = luteolin, while via $\mathrm{hER} \beta$ it was $\mathrm{E}_{2}>$ genistein $>$ formononetin $>$ naringenin $>$ luteolin. The potency of $\mathrm{E}_{2}$ via hER $\alpha$ was significantly different $(P<$ 0.01 ) from that of genistein, luteolin, and formononetin, while only the potency of genistein was significantly different $(P<$ 0.05 ) from that of luteolin. The potency of $\mathrm{E}_{2}$ via $\mathrm{hER} \beta$ was significantly $(P<0.01)$ higher than that of the polyphenols, except genistein, while the potency of genistein, however, was only significantly different $(P<0.05)$ from that of luteolin and naringenin, but not formononetin. The transactivational efficacy of the various polyphenols via $\mathrm{hER} \alpha$ was luteolin $>$ formononetin $>$ genistein $>E_{2}$, with luteolin and formononetin not significantly different $(P>0.05)$ from $\mathrm{E}_{2}$ and genistein, with the latter not statistically different $(P>0.05)$ from each other. The transactivational efficacy of the various polyphenols via $\mathrm{hER} \beta$ did not differ significantly $(P>0.05)$ from each other or from that of $E_{2}$ and genistein (Table 3). Although both $E_{2}$ and genistein, in contrast to the polyphenols tested, displayed a relatively high potency for both binding and ERE-containing promoter reporter assays via $\mathrm{hER} \beta$, the transactivational efficacy was approximately similar for all polyphenols and $\mathrm{E}_{2}(P>0.05)$.

The DMEs were only able to induce the ERE-containing promoter reporter construct via the $\mathrm{hER} \beta$, but not via $\mathrm{hER} \alpha$ (Table 3) despite the fact that some extracts (from the P104 harvesting) were able to displace ${ }^{3} \mathrm{H}-\mathrm{E}_{2}$ from both $\mathrm{hER} \beta$ and $\mathrm{hER} \alpha$, with higher $\mathrm{RBAs}$ for $\mathrm{hER} \alpha$ than for $\mathrm{hER} \beta$ (Table 2). The order of potency $\left(\mathrm{EC}_{50}\right)$ of $\mathrm{E}_{2}$, genistein, and extracts was as follows for $\mathrm{hER} \beta$ : $\mathrm{E}_{2}>$ genistein $>\mathrm{O} \mathrm{P122}>\mathrm{O} \mathrm{P} 104>$ N P104 > O P105 > N P122 > N P105 (Table 3). Potencies of extracts, via hER $\beta$, were not significantly $(P>0.05)$ different from that of $\mathrm{E}_{2}$, except for N P104 and O P105, while none of the extracts were significantly different from genistein. The efficacy of the extracts, via hER $\beta$, was not significantly different $(P>0.05)$ from that of either genistein or $\mathrm{E}_{2}$.

Proliferation of Breast Cancer Cells. All polyphenols investigated were able to induce cell proliferation of the MCF7-BUS cells in a dose-dependent manner with the order of potency being $\mathrm{E}_{2} \gg$ naringenin $>$ genistein $>$ luteolin $>$ formononetin $>$ mangiferin (Table 4). All of the potencies of the polyphenols were significantly different $(P<0.05)$ from that of $\mathrm{E}_{2}$ but not significantly $(P>0.05)$ different from that of genistein. The order of efficacy for the cell proliferation of the MCF-7-BUS cells was genistein $>\mathrm{E}_{2}>$ naringenin $>$ mangiferin $>$ formononetin $>$ luteolin (Table 4). None of the efficacy values determined for the polyphenols were significantly $(P>0.05)$ different from that of $\mathrm{E}_{2}$ or genistein except for luteolin and formononetin $(P<0.01)$. Neither the polyphenols nor $E_{2}$ were able to induce significant proliferation of the MDA-MB-231 cells (Table 4).

DMEs from harvestings P104 and P105 were able to induce cell proliferation of both human breast cancer cells, whereas DMEs from harvesting P122 were unable to induce proliferation of either of the two cell lines tested (Table 4). The rank order of potency (Table 4) in MCF-7-BUS cells was as follows: $E_{2}$ $\gg$ genistein $>$ N P104 > N P105 > O P104 > O P105. The potency of the DMEs in MCF-7-BUS cells (Table 4) was significantly $(P<0.01)$ lower than that of $\mathrm{E}_{2}$ with only O P104 and $\mathrm{O}$ P105 having a significantly $(P<0.05)$ lower potency than genistein. The rank order of efficacy (Table 4) was as follows: genistein $>$ O P104 $>\mathrm{E}_{2}>\mathrm{N} \mathrm{P104}>\mathrm{N} \mathrm{P105}>\mathrm{O}$ $\mathrm{P} 105$. The efficacy of the DMEs in MCF-7-BUS cells was not significantly $(P>0.05)$ different from that of $\mathrm{E}_{2}$ or genistein with the exception of O P105, which was significantly $(P<$ 0.05 ) different from that of genistein.

Similar to results with MCF-7-BUS cells, P104 and P105 were able to induce, albeit to a lesser extent, cell proliferation of the estrogen-insensitive MDA-MB-231 cell line (Table 4). However, P122, $\mathrm{E}_{2}$, and genistein were unable to induce proliferation. The rank order of potency (Table 4) was as follows: O P104 > N P105 > O P105 > N P104. The potency values for the extracts were not significantly $(P>0.05)$ different from each other (statistical data not shown). The rank order of efficacy (Table 4) was as follows: N P105 > N P104 > O 
Table 4. Potency $\left(\mathrm{EC}_{50}\right)$ and Efficacy (Maximal Fold Induction) Values Determined for $\mathrm{E}_{2}$, Various Polyphenols, and DME from Cell Proliferation Assays in MCF-7-BUS and MDA-MB-231 Cells

\begin{tabular}{|c|c|c|c|c|}
\hline \multirow[b]{2}{*}{$\begin{array}{l}\text { test compounds } \\
\text { or DME }\end{array}$} & \multicolumn{2}{|c|}{ MCF-7-BUS cells } & \multicolumn{2}{|c|}{ MDA-MB-231 } \\
\hline & $\begin{array}{c}\text { potency } \\
\left(E_{50}\right)^{a} \mathrm{mg} / \mathrm{mL}\end{array}$ & $\begin{array}{c}\text { efficacy } \\
\text { (maximal fold induction) }\end{array}$ & $\begin{array}{c}\text { potency } \\
\left(E_{50}\right) \mathrm{mg} / \mathrm{mL}\end{array}$ & $\begin{array}{c}\text { efficacy } \\
\text { (maximal fold induction) }\end{array}$ \\
\hline$E_{2}$ & $2.79 \times 10^{-10}(2.92)^{b \# \# c}$ & $2.14(8.46)$ & $\mathrm{N} / \mathrm{A}^{d}$ & $\mathrm{~N} / \mathrm{A}$ \\
\hline genistein & $1.02 \times 10^{-6}(7.56)^{* \star e}$ & $2.35(10.57)$ & N/A & N/A \\
\hline luteolin & $2.54 \times 10^{-6}(15.77)^{\star \star}$ & $1.26(2.52)^{* \star \# \#}$ & $\mathrm{~N} / \mathrm{A}$ & $\mathrm{N} / \mathrm{A}$ \\
\hline formononetin & $1.48 \times 10^{-5}(14.90)^{\star *}$ & $1.38(4.15)^{\star \star \# \# ~}$ & N/A & $\mathrm{N} / \mathrm{A}$ \\
\hline naringenin & $3.27 \times 10^{-8}(1.60)^{*}$ & $2.08(4.15)$ & $\mathrm{N} / \mathrm{A}$ & $\mathrm{N} / \mathrm{A}$ \\
\hline mangiferin & $3.13 \times 10^{-4}(31.07)^{\star \star *}$ & $1.72(3.44)$ & N/A & $\mathrm{N} / \mathrm{A}$ \\
\hline N P104 & $1.98 \times 10^{-6}(7.34)^{* *}$ & $2.07(17.05)$ & $2.47 \times 10^{-9}(2.66)$ & $1.62(19.31)$ \\
\hline O P104 & $1.34 \times 10^{-4}(17.64)^{\star \star \# \#}$ & $2.17(18.21)$ & $1.39 \times 10^{-10}(18.87)$ & $1.59(25.56)$ \\
\hline N P105 & $6.52 \times 10^{-6}(25.71)^{\star *}$ & $1.82(31.08)$ & $2.62 \times 10^{-10}(16.81)$ & $1.81(32.24)$ \\
\hline OP105 & $1.47 \times 10^{-4}(2.45)^{\star * \#}$ & $1.50(13.37)^{\#}$ & $2.79 \times 10^{-10}(17.23)$ & $1.38(35.85)$ \\
\hline N P122 & $N / A^{e}$ & N/A & N/A & N/A \\
\hline O P122 & $\mathrm{N} / \mathrm{A}$ & $\mathrm{N} / \mathrm{A}$ & $\mathrm{N} / \mathrm{A}$ & $\mathrm{N} / \mathrm{A}$ \\
\hline
\end{tabular}

${ }^{a} \mathrm{EC}_{50}$ values calculated from the log $\mathrm{EC}_{50}$ values of three independent experiments given as the mean $(\mathrm{CV}) .{ }^{b} \mathrm{CV}$ or coefficient of variation calculated from the log $\mathrm{EC}_{50}$ of at least three independent experiments performed in triplicate. ' Statistically different from genistein with "\#” representing $P<0.05$ and "\#”" representing $P<0.01$. ${ }^{d} \mathrm{~N} / \mathrm{A}$ not applicable as it could not be determined. ${ }^{e}$ Satistically different from $E_{2}$ with "*" representing $P<0.05$ and "**" representing $P<0.01$.

P104 > O P105. None of the efficacies were significantly different from each other (statistical data not shown).

To establish whether induced cell proliferation was ER dependent, cells were co-treated with an ER antagonist, ICI 182,780. In MCF-7 BUS cells, co-treatment with $1 \times 10^{-9} \mathrm{M} \mathrm{ICI}$ 182,780 reduced the response induced by all polyphenols (Figure 2A), DMEs (Figure 3A), and $\mathrm{E}_{2}$, suggesting that the proliferation response in these cells is ER-dependent as has been previously suggested $(42,43)$. Similarly, in the MDA-MB-231 cells, ICI 182,780 reduced the minimal induction by all of the polyphenols (Figure 2B) and $\mathrm{E}_{2}$ to that of the level of the control. Induction by the DME in MDA-MB-231 cells, however, was only partially reversed by ICI 182,780 in the case of P104 and P105, while in the case of P122 the antagonist appeared to stimulate induction (Figure 3B).

In addition, the effect of the polyphenols or $C$. genistoides DMEs on $\mathrm{E}_{2}$-induced proliferation in MCF-7 BUS cells was investigated. Physiologically more relevant, this would establish how the polyphenols and extracts would react in the presence of the endogenous ligand. $\mathrm{E}_{2}$ proliferation in MCF-7-BUS cells was significantly $(P<0.05)$ prevented by co-treatment with all of the polyphenols, except mangiferin (Figure 4A) and all of the DMEs (Figure 4B), including P122, despite the fact that P122 did not induce cell proliferation on its own (Table 4). The polyphenols, genistein, luteolin, formononetin, and naringenin, and the DME, therefore antagonized $\mathrm{E}_{2}$-induced proliferation and appeared to act as anti-estrogens in the presence of $1 \times 10^{-9} \mathrm{M} \mathrm{E}_{2}$.

Binding to SHBG and Displacement of $\mathbf{E}_{2}$. The percentage of ${ }^{3} \mathrm{H}-\mathrm{E}_{2}$ displaced from SHBG by the polyphenols (Figure 5A) and $C$. genistoides DME (Figure 5B) was significant $(P<0.05)$, except in the case of mangiferin. Displacement by naringenin, which was higher than that of genistein, was not significantly different (statistical data not shown) from that of $E_{2}$, similar to what was found by others (44). In addition, N P104 and O P122 were also as effective as $\mathrm{E}_{2}$ in competing with ${ }^{3} \mathrm{H}-\mathrm{E}_{2}$ for binding to the SHBG (statistical data not shown).

HPLC and LC-MS Analysis. The polyphenols quantified in the $C$. genistoides DME included formononetin, luteolin, naringenin, and mangiferin, as their estogenicity was tested in this study. In addition, these polyphenols had also been shown to be present in $C$. intermedia and $C$. subternata $(2,3)$. Levels of isomangiferin, eriocitrin, narirutin, hesperidin, hesperetin, and isosakuranetin were also evaluated as they had been shown to
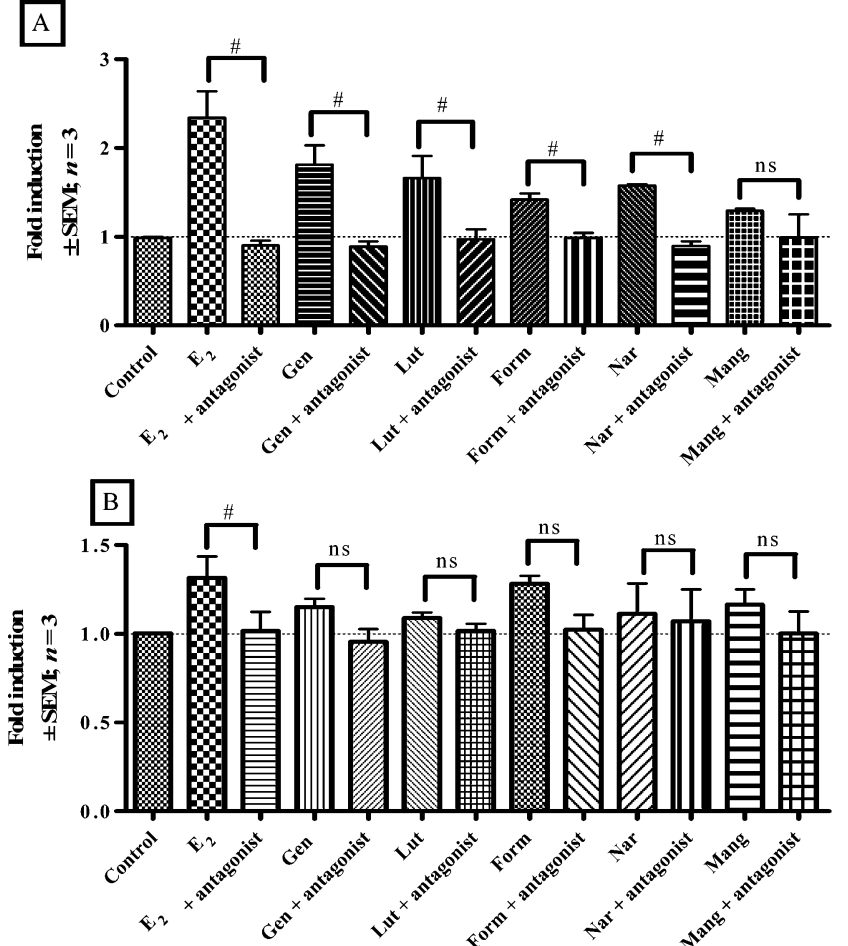

Figure 2. Cell proliferation of polyphenols and $E_{2}$ in (A) MCF-7-BUS and (B) MDA-MB-231 breast cancer cells. Co-treatment with ER antagonist, ICI 182,780, identifies if induced response is ER-dependent. All compounds were tested at $10 \times 10^{-6} \mathrm{M}$ except for $\mathrm{E}_{2}$ and genistein, which were investigated at $1 \times 10^{-9}$ and $0.1 \times 10^{-6} \mathrm{M}$, respectively. The control represents vehicle (DMSO) only. Statistical analysis compared induction by a specific compound in the absence and presence of the ER antagonist using two-tailed $t$ tests $(\#=P<0.05$; ns $=P>0.05$ or not significantly different). Abbreviations: genistein (Gen), luteolin (Lut), formononetin (Form), naringenin (Nar), and mangiferin (Mang).

be present in some Cyclopia species, although a previous study (22) showed that only eriocitrin, narirutin, and eriodictyol bound to the $\operatorname{ER} \beta$. Peaks corresponding to luteolin, eriocitrin, and narirutin were identified on the HPLC chromatogram (Figure 6). However, the peaks eluting at retention times similar to those of eriocitrin and narirutin are of unknown compounds as their mass was different from that of the pure standards (Table 5). Their UV-vis spectra and retention times suggest that these 

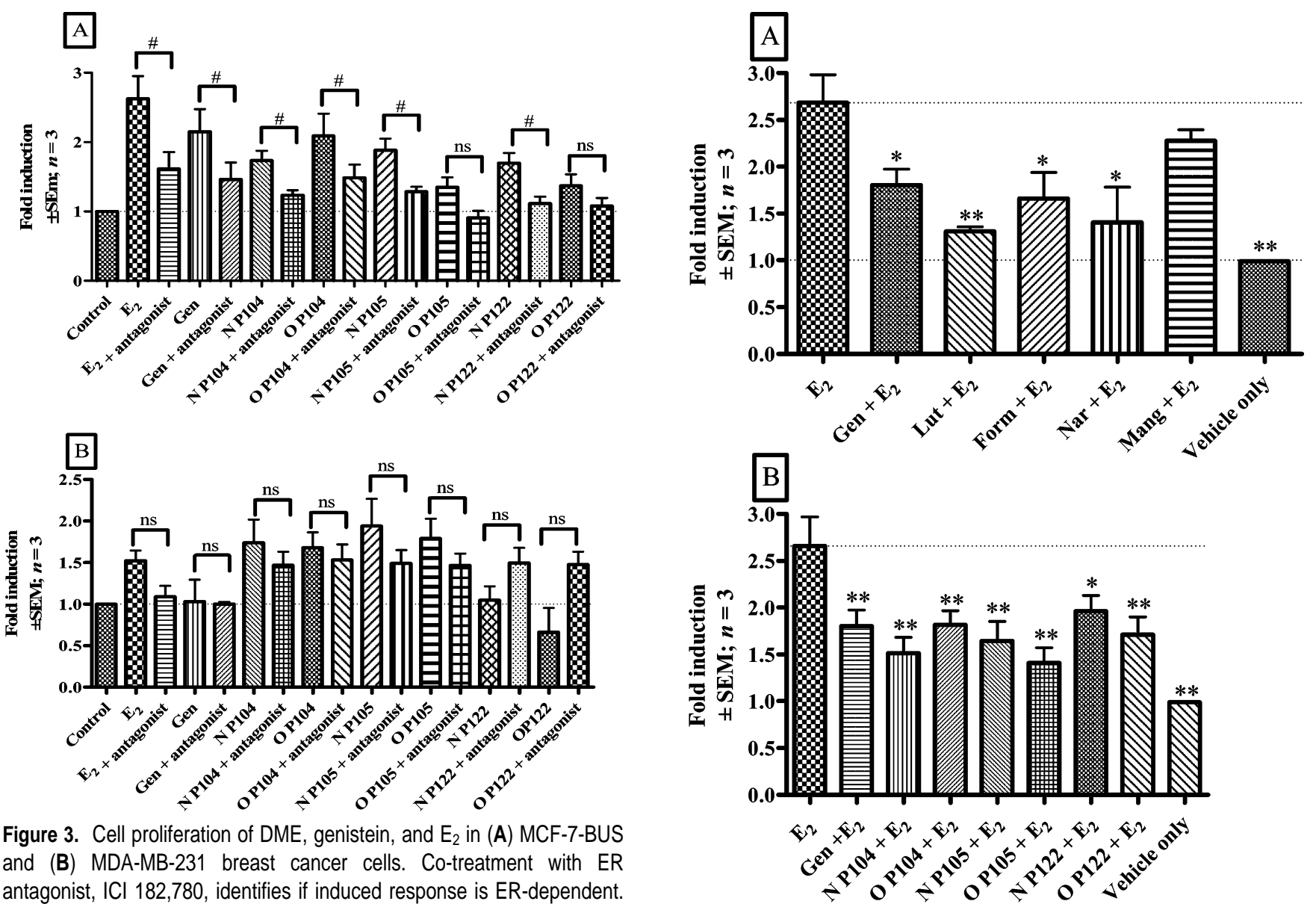

Figure 3. Cell proliferation of DME, genistein, and $E_{2}$ in (A) MCF-7-BUS and (B) MDA-MB-231 breast cancer cells. Co-treatment with ER antagonist, ICI 182,780, identifies if induced response is ER-dependent. All extracts were investigated at $9.8 \mu \mathrm{g} / \mathrm{mL}$, and $E_{2}$ and genistein at $1 \times$ $10^{-9}$ and $10 \times 10^{-6} \mathrm{M}$, respectively. The control represents vehicle (DMSO) only. Statistical analysis compared induction by a DME in the absence and presence of the ER antagonist using two-tailed $t$ tests ( ${ }^{*}=$ $P<0.05$; ns $=P>0.05$ or not significantly different). Abbreviations: genistein (Gen).

two compounds are flavanone glycosides with $\lambda_{\max }$ between 280 and $290 \mathrm{~nm}$. Three other unknown peaks were observed at retention times of 3.7, 10.0, and $16.5 \mathrm{~min}$ (Figure 6). The latter two peaks also had UV-vis spectra similar to those of flavanones.

\section{DISCUSSION}

The presence of the phytoestrogens, formononetin, naringenin, and luteolin, in Cyclopia, coupled to anecdotal evidence of its use for the treatment of menopausal symptoms, led to the investigation of phytoestrogenic activity in Cyclopia as a potential source of phytoestrogens indigenous to South Africa $(2,3)$. A previous study (22) identified $C$. genistoides, among the four species of Cyclopia tested, as the most consistent in demonstrating phytoestrogenic activity through binding to the ER subtypes. Thus, in the present study, DMEs from unfermented $C$. genistoides were chosen for further in-depth study using several estrogenic endpoints to establish and evaluate estrogenicity and to compare estrogenicity with that of the known phytoestrogen, genistein, and the natural ligand, $\mathrm{E}_{2}$. Luteolin, formononetin, naringenin, and mangiferin were included in the study as plant polyphenols previously shown to be present in Cyclopia species $(2,3,45)$, and all, except mangiferin, demonstrated ability to bind to both ER subtypes (22). Mangiferin was chosen as it is the most abundant polyphenol present in honeybush $(45,46)$.

Figure 4. Effect of $(\mathbf{A})$ various polyphenols and $(\mathbf{B})$ C. genistoides $\mathrm{DME}$ on $\mathrm{E}_{2}\left(1 \times 10^{-9} \mathrm{M}\right)$-induced proliferation of MCF-7-BUS. All polyphenols were investigated at $10 \times 10^{-6} \mathrm{M}$, and the DME was investigated at 9.8 $\mu \mathrm{g} / \mathrm{mL}$. Statistical analysis compared cell proliferation induced by $1 \times$ $10^{-9} \mathrm{M} \mathrm{E}_{2}$ only with that induced by $1 \times 10^{-9} \mathrm{M} \mathrm{E}_{2}$ plus polyphenols or DME using one-way ANOVA with Dunnet's multiple comparisons' post test $\left({ }^{*} P<0.05 ;{ }^{*} P<0.01\right)$. Abbreviations: genistein (Gen), luteolin (Lut), formononetin (Form), naringenin (Nar), and mangiferin (Mang).

The $C$. genistoides extracts all induced transactivation via $\operatorname{hER} \beta$, but not $\mathrm{hER} \alpha$, despite the fact that only one harvesting, P104, bound to the ER (Tables 2 and 3). Proliferation studies in MCF-7 cells (Table 4) showed that all but one harvesting, P122, induced proliferation with potency similar to that of genistein.

By using the ER antagonist, ICI 182,780, proliferation by polyphenols in MCF-7 cells was established to be via the ER (Figure 2). MCF-7 cell proliferation induced by DMEs was only partially, although significantly, reversed by ICI 182,780 (Figure 3A), while all of the extracts, except P122, induced cell proliferation in the MDA-MB-231 cells (Figure 3B), which could not be effectively blocked with the ER antagonist. This suggests that, in addition to an ER-dependent mechanism of action, the extracts may also display an ER-independent mechanism of action. Confirmation of this would, however, require further study.

In addition to measuring and validating phytoestrogenic activity, SHBG binding was also measured. All of the polyphenols, except mangiferin, and DME were able to significantly $(P<0.01)$ compete with ${ }^{3} \mathrm{H}-\mathrm{E}_{2}$ for binding to SHBG implying that they can be transported in the bloodstream through binding to SHBG, which would consequently decrease metabolic clearance rate and subsequent excretion as was proposed for 

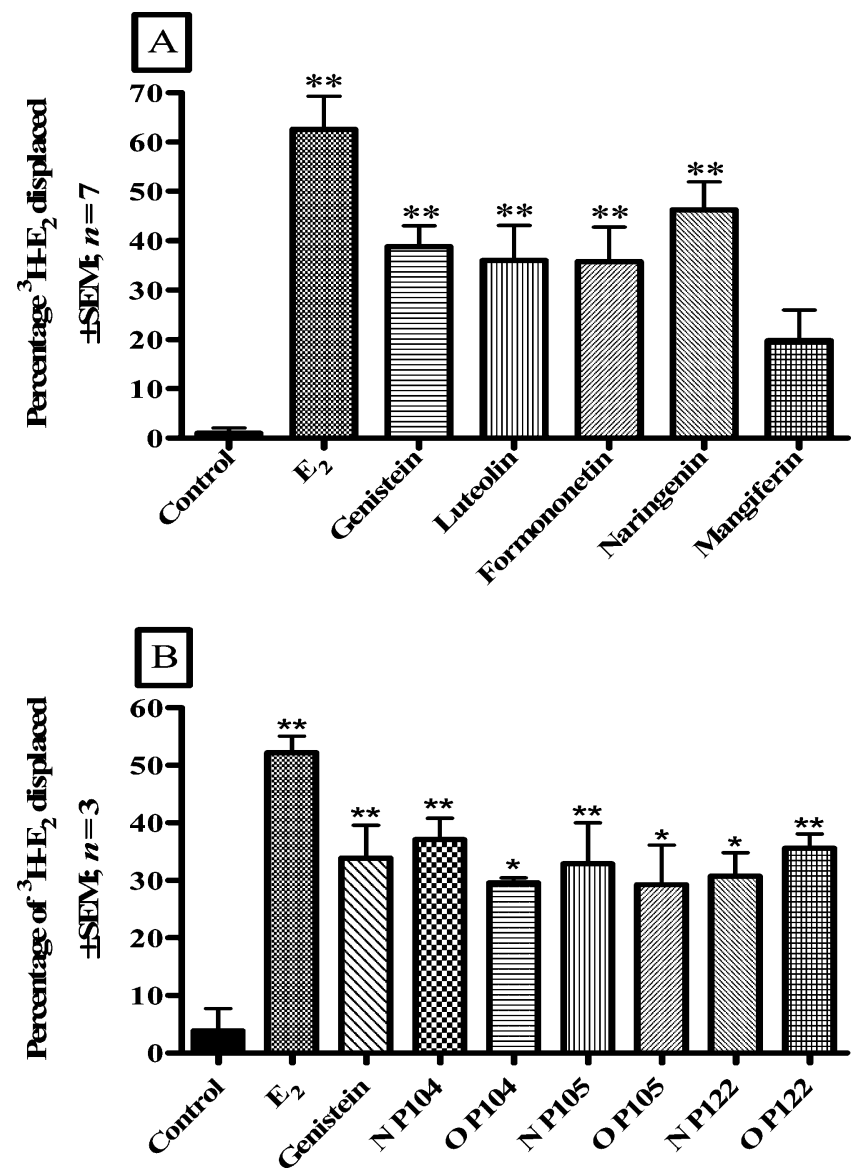

Figure 5. Competitive binding of $(\mathbf{A})$ polyphenols and $(\mathbf{B})$ C. genistoides DME to SHBG in DCC stripped human pregnancy serum incubated with $20 \times 10^{-9} \mathrm{M}^{3} \mathrm{H}-\mathrm{E}_{2}$. Polyphenols and $\mathrm{E}_{2}$ were used at a concentration of $10^{-5} \mathrm{M}$ and the extracts at a concentration of $9.8 \mu \mathrm{g} / \mathrm{mL}$. The control in both represents vehicle (DMSO) only. For statistical analysis, one-way ANOVA was used with Dunnet's multiple comparisons' post test comparing percentage ${ }^{3} \mathrm{H}-\mathrm{E}_{2}$ displaced to control. $P$-values are represented as follows: $P<0.05$ by ${ }^{*}, P<0.01$ by ${ }^{* *}$.

endogenous estrogens $(37,47)$. For future studies, it would be interesting to investigate whether extracts of $C$. genistoides and relevant polyphenols would increase the secretion of SHBG from liver cells as it has been shown that phytoestrogens can increase the synthesis of SHBG $(48,49)$, and an increase in the concentration of SHBG would affect the amount of biologically free steroid $(36,47)$.

Two attributes of phytoestrogens, weak estrogenicity and preference for $\operatorname{ER} \beta$, have been linked to their beneficial health effects $(7,50-52)$. Both attributes are to be discussed here as they pertain to the results obtained with $C$. genistoides extracts. To facilitate evaluation, we will also compare activities with that of $E_{2}$, the endogenous estrogen linked to both adverse (53, 54 ) and beneficial health effects (53), and genistein, a wellstudied phytoestrogen (5).

It has been suggested that the weak estrogenic potential of phytoestrogens may contribute to health-promoting effects such as protecting against the onset of osteoporosis, cardiovascular disease, and certain hormone dependent cancers (7, 50-52). The DMEs and polyphenols tested were consistently less $\left(10^{2}-\right.$ $10^{5}$ times) potent than $\mathrm{E}_{2}$ (Tables $\mathbf{2}-\mathbf{4}$ ). Other studies have shown similar decreases in potencies for genistein as compared to $\mathrm{E}_{2}$ in ER binding, transactivation, and proliferation studies $(27,55,56)$.

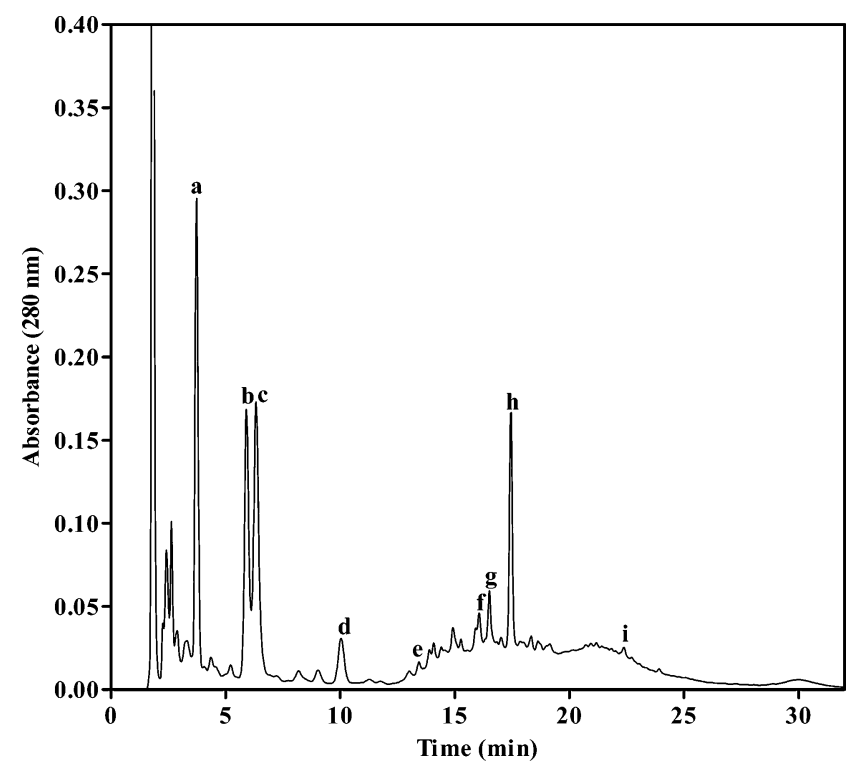

Figure 6. Typical HPLC chromatogram of a DME showing the polyphenols co-eluting at retention times similar to those of known standards: (a) unknown at $3.7 \mathrm{~min}$, (b) mangiferin, (c) isomangiferin, (d) unknown flavanone glycoside at $10.0 \mathrm{~min}$, (e) unknown flavanone glycoside at 13.4 min, (f) unknown flavanone glycoside at $16.0 \mathrm{~min},(\mathbf{g})$ unknown flavanone glycoside at $16.5 \mathrm{~min}$, (h) hesperidin, and (i) luteolin.

The hER $\beta$ is believed to be a modulator of hER $\alpha$ activity as it inhibits proliferation of breast cancer cells and immature rat uterus $(34,57,58)$. It has been shown, in ER $\alpha$ containing T47D breast cancer cells, that $\mathrm{ER} \beta$ inhibits $\mathrm{E}_{2}$-induced cell proliferation if the cells are transfected with $\operatorname{ER} \beta$ to such an extent that the mRNA levels of the two ER subtypes were equal (34). These findings would suggest that either $\operatorname{ER} \beta$ has an anti-proliferative effect on breast cancer cells or it quenches ER $\alpha$ activity (34, 59). Competitive binding with both ER subtypes was investigated as numerous studies have shown that phytoestrogens bind preferentially to the $\operatorname{ER} \beta(26,27,60,61)$. The present study indeed demonstrated that the phytoestrogens, genistein, luteolin, and naringenin, but not formononetin, bind with a higher affinity to the $\mathrm{ER} \beta$ subtype (Table 2 ), confirming results by others (25, 26, 60-63). Formononetin, however, had a slight binding preference for $\mathrm{hER} \alpha$, which is contrary to what others have shown $(61,62)$ and differs from what is found for most phytoestrogens $(26,27,60)$.

Not only did all polyphenols, except mangiferin, bind to $\operatorname{ER} \beta$, they also preferentially transactivated via $\operatorname{ER} \beta$ (Table 3) and induced cell proliferation of MCF-7-BUS cells (Table 4). Of the three harvestings of $C$. genistoides tested, only one, P104, bound to the ER subtypes. Unlike the phytoestrogens, however, it bound preferentially to the hER $\alpha$, like $\mathrm{E}_{2}$ (Table 2). Other plant extracts such as red wine, Ginkgo biloba, kudzu root, and red clover extracts have been shown to have binding affinity for both ER subtypes, but with a higher binding affinity for $\operatorname{ER} \beta(62,64-66)$. It was therefore not expected that the $C$. genistoides methanol extracts would preferentially bind to the $\mathrm{hER} \alpha$. However, despite binding preferentially to the $\mathrm{hER} \alpha$ and binding to the $\operatorname{hER} \beta$ with a potency significantly $(P<0.001)$ lower than that of either $\mathrm{E}_{2}$ or genistein, P104 was able to transactivate an ERE-containing reporter promoter via $\mathrm{hER} \beta$, but not via $\mathrm{ER} \alpha$, with a potency similar to that of $\mathrm{E}_{2}$ and genistein and to induce MCF-7 cell proliferation with a potency similar to that of genistein but significantly $(P<0.01)$ lower than that of $\mathrm{E}_{2}$ (Table 4). In addition, although P105 and P122 were unable to compete with ${ }^{3} \mathrm{H}-\mathrm{E}_{2}$ for binding to $\mathrm{hER} \beta$, both 
Table 5. Phenolic Content, As Determined by HPLC, of the DME

\begin{tabular}{|c|c|c|c|c|c|c|c|c|c|c|c|}
\hline \multirow[b]{2}{*}{ DME } & \multicolumn{11}{|c|}{ percentage of soluble solids ${ }^{a}$} \\
\hline & mangiferin & isomangiferin & eriocitrin & narirutin & hesperidin & luteolin & eriodictyol & naringenin & hesperetin & formononetin & isosakuranetin \\
\hline O P104 & 3.606 & 5.094 & $n d^{b}$ & nd & 1.277 & 0.096 & nd & nd & nd & nd & nd \\
\hline N P104 & 4.264 & 4.901 & nd & nd & 1.728 & 0.097 & nd & nd & nd & nd & nd \\
\hline O P105 & 3.292 & 3.955 & nd & nd & 1.190 & 0.090 & nd & nd & nd & nd & nd \\
\hline N P105 & 6.498 & 4.250 & nd & nd & 2.153 & 0.097 & nd & nd & nd & nd & nd \\
\hline O P122 & 2.977 & 4.934 & nd & nd & 1.243 & 0.106 & nd & nd & nd & nd & nd \\
\hline N P122 & 4.228 & 4.835 & nd & nd & 1.522 & 0.104 & nd & nd & nd & nd & nd \\
\hline
\end{tabular}

${ }^{a}$ Quantities were expressed as a percentage of the extract. ${ }^{b} \mathrm{nd}=$ not detected.

extracts were able to induce transactivation via the $\operatorname{hER} \beta$, but not the ER $\alpha$, and P105 was also able to induce proliferation. These results seem to suggest that the $C$. genistoides extracts are disproportionably effective in activating the hER $\beta$. Further evidence for the activity of the extracts through $\mathrm{hER} \beta$ comes from their ability to antagonize $\mathrm{E}_{2}$-induced cell proliferation of MCF-7-BUS cells (Figure 4B), also seen with the polyphenols, genistein, luteolin, formononetin, and naringenin (Figure 4A) and as shown by others $(67,69,70)$. Polyphenols and extracts, which are able to act preferentially via $\operatorname{hER} \beta$, could be of physiological importance as this could play a role in the prevention of excessive cell proliferation, which is associated with cancer formation (31).

Investigations into the estrogenic activity of other plant extracts have yielded results similar to those found in the present study. Kudzu root, soybean, red clover, and alfalfa sprout displayed agonist activity through the ERE-containing promoter reporter assays by activating both $\mathrm{ER} \alpha$ and $\mathrm{ER} \beta$, with preferential activation of $\mathrm{ER} \beta$ observed (66). In addition, extracts from Moghania philippinensis (71), kudzu root, red clover, alfalfa sprout, and soybean (66) could also induce MCF-7 cell proliferation. Additionally, Ginkgo biloba extracts were shown to induce proliferation of MCF-7 cells that is ER-dependent as the response could be blocked with an ER antagonist $(65,66)$. The Ginkgo biloba extracts could, however, not induce cell proliferation of MDA-MB-231 cells (65). On the other hand, methanol extracts from $M$. philipinensis have previously been shown to antagonize MCF-7 cell proliferation induced by $\mathrm{E}_{2}$ (71).

HPLC and LC-MS analysis (Table 5 and Figure 6) shows that of the polyphenols tested for estrogenicity only luteolin is present in detectable quantities. The amount of luteolin present $(0.096-0.106 \mathrm{~g} / 100 \mathrm{~g})$ is, however, too low to explain the fact that in MCF-7-BUS cell proliferation, for example, two DMEs (N P104 and N P105) show potencies similar to that of luteolin. Five unknown peaks $(\mathrm{a}, \mathrm{d}-\mathrm{g})$ are observed in the HPLC chromatogram. Of these, four $(\mathrm{d}-\mathrm{g})$ are most probably unknown flavanone glycosides based on their UV-vis spectra $\left(\lambda_{\max }\right)$ and relative retention time to the other flavanone glycoside. The fact that the DME behaved differently from the polyphenols tested in that they induced proliferation via the estrogeninsensitive MDA-MB-231 cell line, which was only partially reversed by the ER antagonist ICI 182,780, suggests that these unknown peaks may represent novel compounds present in the DMEs with biological activity that differs from that of the polyphenols tested. Confirmation of the estrogenic potential of these unknown peaks awaits further study.

To summarize, the present study showed that the polyphenols, luteolin, formononetin, and naringenin, present in Cyclopia spp. and some DMEs from $C$. genistoides are estrogenic in vitro through binding to both ER subtypes, inducing transactivation via $\operatorname{hER} \beta$, and by inducing cell proliferation of the estrogen sensitive MCF-7-BUS cells. Proliferation of the estrogeninsensitive MDA-MB-231 cell line was, however, only stimulated by DMEs. Although the present study showed that $C$. genistoides is a potential source of phytoestrogens, caution should, however, be exercised as variation within the species does exist. DME from only one harvesting (P104) was able to displace ${ }^{3} \mathrm{H}-\mathrm{E}_{2}$ from the ER subtypes, and DMEs of only two harvestings (P104 and P105) were able to induce proliferation of the MCF-7-BUS cells, while all three DMEs (P104, P105, and P122) portrayed estrogenicity through induction of the EREcontaining promoter reporter via $\mathrm{ER} \beta$. The variations in estrogenicity may be ascribed to polyclonal plant material and stress factors such as temperature and soil requirements (72, 73). Therefore, each individual batch of plant material available at this stage in the industry would probably have to be screened if it is to be used to prepare a nutraceutical.

\section{ACKNOWLEDGMENT}

We sincerely thank C. Langeveldt for her skillful technical assistance, especially for the maintenance and culturing of the COS- 1 cells, and Dalene de Beer for the HPLC and LC-MS analysis. We thank Fritz Joubert of Koksrivier, Pearly Beach, Overberg, for providing honeybush plant material.

\section{LITERATURE CITED}

(1) Richards, E. S. Antioxidant and antimutagenic activities of Cyclopia species and activity-guided fractionation of $C$. intermedia. M.Sc. Thesis, University of Stellenbosch, 2002.

(2) Ferreira, D.; Kamara, B. I.; Brandt, E. V.; Joubert, E. Phenolic compounds from Cyclopia intermedia (honeybush tea). 1. J. Agric. Food Chem. 1998, 46, 3406-3410.

(3) Kamara, B. I.; Brand, D. J.; Brandt, E. V.; Joubert, E. Phenolic metabolites from honeybush tea (Cyclopia subternata). J. Agric. Food Chem. 2004, 52, 5391-5395.

(4) Murkies, A. L.; Wilcox, G.; Davis, S. R. Phytoestrogens. J. Clin. Endocrinol. Metab. 1998, 83, 297-303.

(5) Dixon, R. A.; Ferreira, D. Genistein. Phytochemistry 2002, 60, 205-211.

(6) Beck, V.; Rohr, U.; Jungbauer, A. Phytoestrogens derived from red clover: an alternative to estrogen replacement therapy? $J$. Steroid Biochem. Mol. Biol. 2005, 94, 499-518.

(7) Tham, D. M.; Gardner, C. D.; Haskell, W. L. Potential health benefits of dietary phytoestrogens: A review of the clinical, epidemiological, and mechanistic evidence. J. Clin. Endocrinol. Metab. 1998, 83, 2223-2235.

(8) Morton, M. S.; Arisaka, O.; Miyake, N.; Morgan, L. D.; Evans, B. A. J. Phytoestrogen concentrations in serum from Japanese men and women over forty years of age. J. Nutr. 2002, 132, 3168-3171.

(9) Fritz, W. A.; Coward, L.; Wang, J.; Lamartiniere, C. A. Dietary genistein: perinatal mammary cancer prevention, bioavailability and toxicity testing in the rat. Carcinogenesis 1998, 19, 21512158. 
(10) Brzezinski, A.; Adlercreutz, H.; Shaoul, R.; Rösler, A.; Shmueli, A.; Tanos, V.; Schenker, J. G. Short-term effects of phytoestrogen-rich diet on postmenopausal women. Menopause: The Journal of The North American Menopause Society 1997, 4, 8994.

(11) van de Weijer, P. H.; Barentsen, R. Isoflavones from red clover (Promensil) significantly reduce menopausal hot flush symptoms compared with placebo. Maturitas 2002, 42, 187-193.

(12) de Kleijn, M. J. J.; van der Schouw, Y. T.; Wilson, P. W. F.; Grobbee, D. E.; Jacques, P. F. Dietary intake of phytoestrogens is associated with a favourable metabolic cardiovascular risk profile in postmenopausal U.S. women: The Framingham study. J. Nutr. 2002, 132, 276-282.

(13) Potter, S. M.; Baum, J. A.; Teng, H.; Stillman, R. J.; Shay, N. F.; Erdman, J. W., Jr. Soy protein and isoflavones: their effects on blood lipids and bone density in postmenopausal women. Am. J. Clin. Nutr. 1998, 68, 1375S-1379S.

(14) Nikander, E.; Metsa-Heikkila, M.; Ylikorkala, O.; Tiitinen, A. Effects of phytoestrogens on bone turnover in postmenopausal women with a history of breast cancer. J. Clin. Endocrinol. Metab. 2004, 89, 1207-1212.

(15) Tice, J. A.; Ettinger, B.; Ensrud, K.; Wallace, R.; Blackwell, T.; Cummings, S. R. Phytoestrogen supplements for the treatment of hot flashes: the Isoflavone Clover Extract (ICE) Study: a randomized controlled trial. JAMA, J. Am. Med. Assoc. 2003, 290, 207-214.

(16) Burke, G. L.; Legault, C.; Anthony, M.; Bland, D. R.; Morgan, T. M.; Naughton, M. J.; Leggett, K.; Washburn, S. A.; Vitolins, M. Z. Soy protein and isoflavone effects on vasomotor symptoms in peri- and postmenopausal women: the Soy Estrogen Alternative Study. Menopause 2003, 10, 147-153.

(17) Glazier, M. G.; Bowman, M. A. A review of the evidence for the use of phytoestrogens as a replacement for traditional estrogen replacement therapy. Arch. Intern. Med. 2001, 161, 1161-1172.

(18) Beral, V. Breast cancer and hormone-replacement therapy in the Million Women Study. Lancet 2003, 362, 419-427.

(19) Writing Group for the Women's Health Initiative Investigators. Risks and Benefits of Estrogen Plus Progestin in Healthy Postmenopausal Women: Principal Results From the Women's Health Initiative Randomized Controlled Trial. JAMA, J. Am. Med. Assoc. 2002, 288, 321-333.

(20) The Women's Health Initiative Steering Committee. Effects of Conjugated Equine Estrogen in Postmenopausal Women With Hysterectomy: The Women's Health Initiative Randomized Controlled Trial. JAMA, J. Am. Med. Assoc. 2004, 291, 17011712 .

(21) Eisenberg, D. M.; Davis, R. B.; Ettner, S. L.; Appel, S.; Wilkey, S.; Van Rompay, M.; Kessler, R. C. Trends in alternative medicine use in the United States, 1990-1997: Results of a follow-up national survey. JAMA, J. Am. Med. Assoc. 1998, 280, $1569-1575$

(22) Verhoog, N. J. D.; Joubert, E.; Louw, A. Screening of four Cyclopia (honeybush) species for putative phytoestrogenic activity through estrogen receptor binding assays. S. Afr. J. Sci. 2007, 103, 13-21.

(23) Nilsson, S.; Makela, S.; Treuter, E.; Tujague, M.; Thomsen, J.; Andersson, G.; Enmark, E.; Pettersson, K.; Warner, M.; Gustafsson, J. A. Mechanisms of estrogen action. Physiol. Rev. 2001, $81,1535-1565$

(24) Mangelsdorf, D. J.; Thummel, C.; Beato, M.; Herrlich, P.; Schutz, G.; Umesono, K.; Blumberg, B.; Kastner, P.; Mark, M.; Chambon, P.; Evans, R. M. The nuclear receptor superfamily: the second decade. Cell 1995, 83, 835-839.

(25) Morito, K.; Hirose, T.; Kinjo, J.; Hirakawa, T.; Okawa, M.; Nohara, T.; Ogawa, S.; Inoue, S.; Muramatsu, M.; Masamune, Y. Interaction of phytoestrogens with estrogen receptors $\alpha$ and B. Biol. Pharm. Bull. 2001, 24, 351-356.

(26) Kuiper, G. G. J. M.; Lemmen, J. G.; Carlsson, B.; Corton, J. C.; Safe, S. H.; van der Saag, P. T.; van der Burg, B.; Gustafsson, $\mathrm{J}$. A. Interaction of estrogenic chemicals and phytoestrogens with estrogen receptor $\beta$. Endocrinology 1998, 139, 4252-4263.
(27) Mueller, S. O.; Simon, S.; Chae, K.; Metzler, M.; Korach, K. S. Phytoestrogens and their human metabolites show distinct agonistic and antagonistic properties on estrogen receptor $\alpha$ and estrogen receptor $\beta$ in human cells. Toxicol. Sci. 2004, 80, 1425

(28) An, J.; Tzagarakis-Foster, C.; Scharschmidt, T. C.; Lomri, N.; Leitman, D. C. Estrogen receptor beta-selective transcriptional activity and recruitment of coregulators by phytoestrogens. $J$. Biol. Chem. 2001, 276, 17808-17814.

(29) Gruber, C. J.; Tschugguel, W.; Schneeberger, C.; Huber, J. C. Production and actions of estrogens. N. Engl. J. Med. 2002, 346, 340-352.

(30) Mueller, S. O. Overview of in vitro tools to assess the estrogenic and antiestrogenic activity of phytoestrogens. J. Chromatogr., B 2002, 777, 155-165.

(31) Stopper, H.; Schmitt, E.; Gregor, C.; Mueller, S. O.; Fischer, W. H. Increased cell proliferation is associated with genomic instability: elevated micronuclei frequencies in estradiol-treated human ovarian cancer cells. Mutagenesis 2003, 18, 243-247.

(32) Paech, K.; Webb, P.; Kuiper, G. G.; Nilsson, S.; Gustafsson, J. A.; Kushner, P. J.; Scanlan, T. S. Differential ligand activation of estrogen receptors ER $\alpha$ and ER $\beta$ at AP1 sites. Science 1997, 277, 1508-1510.

(33) Lindberg, M. K.; Moverare, S.; Skrtic, S.; Gao, H.; DahlmanWright, K.; Gustafsson, J. A.; Ohlsson, C. Estrogen receptor (ER)-beta reduces ERalpha-regulated gene transcription, supporting a "Ying Yang" relationship between ERalpha and ERbeta in mice. Mol. Endocrinol. 2003, 17, 203-208.

(34) Strom, A.; Hartman, J.; Foster, J. S.; Kietz, S.; Wimalasena, J.; Gustafsson, J. A. Estrogen receptor-beta inhibits $17-\beta$-estradiolstimulated proliferation of the breast cancer cell line T47D. Proc. Natl. Acad. Sci. U.S.A. 2004, 101, 1566-1571.

(35) Hammond, G. L. Potential functions of plasma steroid-binding proteins. Trends Endocrinol. Metab. 1995, 6, 298-304.

(36) Mendel, C. M. The free hormone hypothesis: a physiologically based mathematical model. Endocrinol. Rev. 1989, 10, 232274.

(37) Plymate, S. R.; Namkung, P. C.; Metej, L. A.; Petra, P. H. Direct effect of plasma sex hormone binding globulin (SHBG) on the metabolic clearance rate of 17 beta-estradiol in the primate. $J$. Steroid Biochem. 1990, 36, 311-317.

(38) Dotzlaq, H.; Leygue, E.; Watson, P. H.; Murphy, L. C. Expression of estrogen receptor- $\beta$ in human breast tumors. $J$. Clin. Endocrinol. Metab. 1997, 82, 2371-2374.

(39) Bradford, M. M. A rapid and sensitive method for the quantitation of microgram quantities of protein utilizing the principle of protein-dye binding. Anal. Biochem. 1976, 72, 248-254.

(40) Hammond, G. L.; Lahteenmaki, P. L. A versatile method for the determination of serum cortisol binding globulin and sex hormone binding globulin binding capacities. Clin. Chim. Acta 1983, 132, 101-110.

(41) Cheng, Y.; Prusoff, W. H. Relationship between the inhibition constant (K1) and the concentration of inhibitor which causes $50 \%$ inhibition (I50) of an enzymatic reaction. Biochem. Pharmacol. 1973, 22, 3099-3108.

(42) Villalobos, M.; Olea, N.; Brotons, J. A.; Olea-Serrano, M. F.; Ruiz de Almodovar, J. M.; Pedraza, V. The E-screen assay: a comparison of different MCF7 cell stocks. Environ. Health Perspect. 1995, 103, 844-850.

(43) Lazennec, G.; Alcorn, J. L.; Katzenellenbogen, B. S. Adenovirusmediated delivery of a dominant negative estrogen receptor gene abrogates estrogen-stimulated gene expression and breast cancer cell proliferation. Mol. Endocrinol. 1999, 13, 969-980.

(44) Hodgert, J. H.; Zacharewski, T. R.; Hammond, G. L. Interactions between human plasma sex hormone-binding globulin and xenobiotic ligands. J. Steroid Biochem. Mol. Biol. 2000, 75, 167-176. 
(45) Joubert, E.; Otto, F.; Grüner, S.; Weinreich, B. Reversed-phase HPLC determination of mangiferin, isomangiferin and hesperidin in Cyclopia and the effect of harvesting date on the phenolic composition of C. genistoides. Eur. Food Res. Technol. 2003, $216,270-273$.

(46) De Nysschen, A. M.; Van Wyk, B. E.; Van Heerden, F. R.; Schutte, A. L. The major phenolic compounds in the leaves of Cyclopia species (Honeybush Tea). Biochem. Syst. Ecol. 1996, 24, 243-246.

(47) Siiteri, P. K.; Murai, J. T.; Hammond, G. L.; Nisker, J. A.; Raymoure, W. J.; Kuhn, R. W. The serum transport of steroid hormones. Recent Prog. Horm. Res. 1982, 38, 457-510.

(48) Loukovaara, M.; Carson, M.; Palotie, A.; Adlercreutz, H. Regulation of sex hormone-binding globulin production by isoflavonoids and patterns of isoflavonoid conjugation in HepG2 cell cultures. Steroids 1995, 60, 656-661.

(49) Mousavi, Y.; Adlercreutz, H. Genistein is an effective stimulator of sex hormone-binding globulin production in hepatocarcinoma human liver cancer cells and suppresses proliferation of these cells in culture. Steroids 1993, 58, 301-304.

(50) Dixon, R. A. Phytoestrogens. Annu. Rev. Plant Physiol. Plant Mol. Biol. 2004, 55, 225-261.

(51) Magee, P. J.; Rowland, I. R. Phyto-oestrogens, their mechanism of action: current evidence for a role in breast and prostate cancer. Br. J. Nutr. 2004, 91, 513-531.

(52) Wuttke, W.; Jarry, H.; Becker, T.; Schultens, A.; Christoffel, V.; Gorkow, C.; Seidlova-Wuttka, D. Phytoestrogens: endocrine disrupters or replacement for hormone replacement therapy? Maturitas 2003, 44, S9-S20.

(53) Conneely, O. M. Perspective: Female steroid hormone action. Endocrinology 2001, 142, 2194-2199.

(54) Cavalieri, E.; Frenkel, K.; Liehr, J. G.; Rogan, E.; Roy, D. Estrogens as endogenous genotoxic agents-DNA adducts and mutations. J. Natl. Cancer Inst. Monogr. 2000, 27, 75-93.

(55) Escande, A.; Pillon, A.; Servant, N.; Cravedi, J. P.; Larrea, F.; Muhn, P. Evaluation of ligand selectivity using reporter cell lines stably expressing estrogen receptor alpha or beta. Biochem. Pharmacol. 2006, 71, 1459-1469.

(56) Bentrem, D.; Fox, J. E.; Pearce, S. T.; Liu, H.; Pappas, S.; Kupfer, D. Zapf, J. W.; Jordan, V. C. Distinct molecular conformations of the estrogen receptor $\alpha$ complex exploited by environmental estrogens. Cancer Res. 2003, 63, 7490-7496.

(57) Lazennec, G.; Bresson, D.; Luca, A.; Chauveau, C.; Vignon, F. $\operatorname{ER} \beta$ inhibits proliferation and invasion of breast cancer cells. Endocrinology 2001, 142, 4120-4130.

(58) Weihua, Z.; Saji, S.; Makinen, S.; Cheng, G.; Jensen, E. V.; Warner, M.; Gustafsson, J. A. Estrogen receptor (ER) beta, a modulator of ERalpha in the uterus. Proc. Natl. Acad. Sci. U.S.A. 2000, 97, 5936-5941.

(59) Hayashi, S. I.; Eguchi, H.; Tanimoto, K.; Yoshida, T.; Omoto, Y.; Inoue, A.; Yoshida, N.; Yamaguchi, Y. The expression and function of estrogen receptor alpha and beta in human breast cancer and its clinical application. Endocrinol. Relat. Cancer 2003, 10, 193-202.

(60) Muthyala, R. S.; Ju, Y. H.; Sheng, S.; Williams, L. D.; Doerge, D. R.; Katzenellenbogen, B. S.; Helferich, W. G.; Katzenellenbogen, J. A. Equol, a natural estrogenic metabolite from soy isoflavones: convenient preparation and resolution of R- and $\mathrm{S}$-equols and their differing binding and biological activity through estrogen receptors alpha and beta. Bioorg. Med. Chem. 2004, 12, 1559-1567.

(61) Liu, J.; Burdette, J. E.; Xu, H.; Gu, C.; van Breemen, R. B.; Bhat, K. P.; Booth, N.; Constantinou, A. I.; Pezzuto, J. M.; Fong, H. H.; Farnsworth, N. R.; Bolton, J. L. Evaluation of estrogenic activity of plant extracts for the potential treatment of menopausal symptoms. J. Agric. Food Chem. 2001, 49, 2472-2479.
(62) Overk, C. R.; Yao, P.; Chadwick, L. R.; Nikolic, D.; Sun, Y.; Cuendet, M. A.; Deng, Y.; Hedayat, A. S.; Pauli, G. F.; Farnsworth, N. R.; van Breemen, R. B.; Bolton, J. L. Comparison of the in vitro estrogenic activities of compounds from hops (Humulus lupulus) and red clover (Trifolium pratense). J. Agric. Food Chem. 2005, 53, 6246-6253.

(63) Han, D. H.; Denison, M. S.; Tachibana, H.; Yamada, K. Relationship between estrogen receptor-binding and estrogenic activities of environmental estrogens and suppression by flavonoids. Biosci. Biotechnol. Biochem. 2002, 66, 14791487.

(64) Klinge, C. M.; Risinger, K. E.; Watts, M. B.; Beck, V.; Eder, R.; Jungbauer, A. Estrogenic activity in white and red wine extracts. J. Agric. Food Chem. 2003, 51, 1850-1857.

(65) Oh, S. M.; Chung, K. H. Estrogenic activities of Ginkgo biloba extracts. Life Sci. 2004, 74, 1325-1335.

(66) Boué, S. M.; Wiese, T. E.; Nehls, S.; Burow, M. E.; Elliott, S.; Carter-Wientjes, C. H.; Shih, B. Y.; McLachlan, J. A.; Cleveland, T. E. Evaluation of the estrogenic effects of legume extracts containing phytoestrogens. J. Agric. Food Chem. 2005, 51, 2193-2199.

(67) Le Bail, J. C.; Nicolas, J. C.; Habrioux, G.; Varnat, F. Estrogenic and antiproliferative activities on MCF-7 human breast cancer cells by flavonoids. Cancer Lett. 1998, 130, 209-216.

(68) Ruh, M. F.; Zacharewski, T.; Connor, K.; Howell, J.; Chen, I.; Safe, S. Naringenin: A weakly estrogenic bioflavonoid that exhibits antiestrogenic activity. Biochem. Pharmacol. 1995, 50, 1485-93.

(69) Markaverich, B. M.; Roberts, R. R.; Alejandro, M. A.; Johnson, G. A.; Middleditch, B. S.; Clark, J. H. Bioflavonoid interaction with rat uterine type II binding sites and cell growth inhibition. J. Steroid Biochem. 1988, 30, 71-78.

(70) Hwang, C. S.; Kwak, H. S.; Lim, H. J.; Lee, S. H.; Kang, Y. S.; Choe, T. B.; Hur, H. G.; Han, K. O. Isoflavone metabolites and their in vitro dual functions: They can act as an estrogenic agonist or antagonist depending on the estrogen concentration. J. Steroid Biochem. Mol. Biol. 2006, 101, 246-253.

(71) Ahn, E. M.; Nakamura, N.; Akao, T.; Nishihara, T.; Hattori, M. Estrogenic and antiestrogenic activities of the roots of Moghania philippinensis and their constituents. Biol. Pharm. Bull. 2004, 27, 548-553.

(72) Lee, S. J.; Kim, S. H.; Kim, J. T.; Han, S. J.; Jung, M. Y.; Chung, I. M.; Ahn, J. K. Variation in isoflavone of soybean cultivars with location and storage duration. J. Agric. Food Chem. 2003, 51, 3382-3389.

(73) Wang, S. Y.; Lin, H. S. Compost as a soil supplement increases the level of antioxidant compounds and oxygen radical absorbance capacity in strawberries. J. Agric. Food Chem. 2003, 51, 6844-6850.

Received for review December 11, 2006. Revised manuscript received March 13, 2007. Accepted March 14, 2007. This work was supported in part by grants to A.L. and E.J. from the Medical Research Council, National Research Foundation (NRF) (GUN 2053898), THRIP (project 2634), National Department of Agriculture (ARC project 270030), and the Western Cape Department of Agriculture (ARC project 270030). Any opinion, findings, and conclusions or recommendations expressed in this material are those of the author(s), and therefore the NRF does not accept any liability in regard thereto.

JF063588N 